Roy, C., N. L. Michel, C. M. Handel, S. L. Van Wilgenburg, J. C. Burkhalter, K. E. B. Gurney, D. J. Messmer, K. Princé, C. S. Rushing, J. F. Saracco, R. Schuster, A. C. Smith, P. A. Smith, P. Sólymos, L. A. Venier, and B. Zuckerberg. 2019. Monitoring boreal avian populations: how can we estimate trends and trajectories from noisy data?. Avian Conservation and Ecology 14(2):8. https://doi.org/10.5751/ACE-01397-140208

Copyright (C) 2019 by the author(s). Published here under license by the Resilience Alliance.

Research Paper, part of a Special Feature on Conservation of Boreal Birds

\title{
Monitoring boreal avian populations: how can we estimate trends and trajectories from noisy data?
}

Christian Roy ${ }^{1}$, Nicole L. Michel ${ }^{2}$, Colleen M. Handel ${ }^{3}$, Steven L. Van Wilgenburg ${ }^{1}$, J. Curtis Burkhalter ${ }^{4}$, Kirsty E. B. Gurney $^{5,6}$, David J. Messmer ${ }^{6}$, Karine Princé ${ }^{7,8,9,10}$, Clark S. Rushing ${ }^{11}$, James F. Saracco ${ }^{12}$, Richard Schuster ${ }^{13,14}$, Adam C. Smith ${ }^{1,13}$, Paul A. Smith $^{5}$, Péter Sólymos ${ }^{15,16,17}$, Lisa A. Venier ${ }^{18}$ and Ben Zuckerberg ${ }^{7}$

${ }^{1}$ Canadian Wildlife Service, Environment and Climate Change Canada, ${ }^{2}$ National Audubon Society, ${ }^{3}$ U.S. Geological Survey, Alaska Science Center, Anchorage, Alaska, USA, ${ }^{4}$ Shearwater Analytics, Jacksonville, Florida, USA, ${ }^{5}$ Science and Technology Branch, Environment and Climate Change Canada, ${ }^{6}$ Department of Biology, University of Saskatchewan, Saskatoon, Saskatchewan, Canada, ${ }^{7}$ Department of Forest and Wildlife Ecology, University of Wisconsin-Madison, Wisconsin, USA, ${ }^{8}$ Muséum National d'Histoire Naturelle, UMR 7204 Centre d'Ecologie et des Sciences de la Conservation (CESCO), Paris, France, ${ }^{9}$ Université de Lyon, Lyon, France, ${ }^{10}$ CNRS, UMR5558, Laboratoire de Biométrie et Biologie Evolutive, Villeurbanne, France,

${ }^{11}$ Department of Wildland Resources and the Ecology Center, Utah State University, Logan, Utah, USA, ${ }^{12}$ The Institute for Bird Populations, ${ }^{13}$ Department of Biology, Carleton University, Ottawa, Ontario, Canada, ${ }^{14}$ Ecosystem Science and Management Program, University of Northern British Columbia, British Columbia, Canada, ${ }^{15}$ Department of Biological Sciences, University of Alberta, ${ }^{16}$ Alberta Biodiversity Monitoring Institute, ${ }^{17}$ Boreal Avian Modelling Project, ${ }^{18}$ Great Lakes Forestry Centre, Canadian Forest Service, Natural Resources Canada, Sault Ste. Marie, Ontario, Canada

ABSTRACT. Substantial effort has been dedicated to developing reliable monitoring schemes for North American bird populations, but our ability to monitor bird populations in the boreal forest remains limited because of the sparsity of long-term data sets, particularly in northerly regions. Given the importance of the boreal forest for many migratory birds, we set out to (1) summarize the main challenges associated with monitoring avian populations, (2) describe the available statistical tools for population monitoring and their applications, and (3) identify future directions to overcome current challenges in monitoring bird populations in the boreal forest. Defining and delineating populations of interest and identifying the drivers that affect those populations present the greatest current challenges. This is because migratory birds may be affected by many population-limiting processes at different stages of their annual life cycles. These factors are often hierarchically structured and can influence populations at the local, regional, or continental scales. Some of the challenges associated with delineating populations and identifying population drivers can be addressed via the plethora of sampling and analytic methods available to examine population change over time. Choosing the proper analytic methods depends on the goals of the study and the nature of the data such as single or multiple populations, repeated occurrence or count-based surveys, or demographic rates. Recent advances in hierarchical and integrated population models make these analytic approaches some of the most promising avenues for the development of future methods. However, these tools require large data sets, and acquiring sufficient data on bird populations and potential explanatory variables is difficult in the boreal forest. If the current challenges to monitoring birds in the boreal forest are to be overcome, serious effort should be dedicated to integrating existing data and making them accessible. Enhancing survey effort through multispecies surveys will also play an important role. Implementing spatially balanced sampling plans with a rotating panel design could balance the trade-offs between spatial versus temporal replication at an affordable cost. Improving the accessibility of environmental covariates that are spatially and temporally explicit would also enable development of mechanistic population models that improve our understanding of migratory bird population dynamics. Finally, given that long-term monitoring programs can take many decades before delivering reliable population trends and that organizational priorities often change over time, we suggest that collaborative efforts will help ensure the long-term survival of new monitoring programs.

\section{Surveillance des populations aviaires boréales : comment estimer les tendances et les trajectoires à partir de données bruyantes?}

RÉSUMÉ. Des efforts considérables ont été consacrés au développement de programmes de surveillance fiable des populations d'oiseaux d'Amérique du Nord. Toutefois, notre capacité à surveiller les populations aviaires dans la forêt boréale reste limitée, en raison de la rareté des jeux de données de longue durée, en particulier dans les régions boréales. Compte tenu de l'importance de la forêt boréale pour de nombreux oiseaux migrateurs, nous avons entrepris (1) de résumer les principaux défis associés à la surveillance des populations aviaires, (2) de décrire les outils statistiques disponibles pour la surveillance des populations et leurs applications et (3) d'identifier les orientations futures afin de surmonter les difficultés actuelles de surveillance des populations aviaires dans la forêt boréale. La définition et la délimitation des populations d'intérêt et l'identification des éléments qui affectent ces populations représentent les principaux défis actuellement. Cela est dû au fait que les oiseaux migrateurs peuvent être affectés par de nombreux processus limitant les populations

Address of Correspondent: Christian Roy, Canadian Wildlife Service, Environment and Climate Change Canada, 351 St. Joseph Boulevard, Gatineau, Quebec K1A0H3, Canada, christian.roy3@canada.ca 
à différents stades de leur cycle de vie annuel. Ces facteurs sont souvent structurés de manière hiérarchique et peuvent influencer les populations aux niveaux local, régional ou continental. Certains des défis associés à la délimitation des populations et l'identification des facteurs qui influencent les populations peuvent être traités à l'aide de la multitude de méthodes d'échantillonnage et d'analyse disponibles pour examiner l'évolution de la population au fil du temps. Le choix de méthodes d'analyse appropriées dépend des objectifs de l'étude et de la nature des données, par exemple des populations uniques ou multiples, les enquêtes répétées ou basées sur des comptes ou les taux démographiques. Les progrès récents des modèles de populations hiérarchiques et intégrés ont fait de certaines de ces approches analytiques les orientations les plus prometteuses pour le développement des méthodes futures. Toutefois, ces outils requièrent d'importants jeux de données; or, l'acquisition de données suffisantes sur les populations aviaires et de variables d'explication potentielles est complexe dans la forêt boréale. Si l'on veut surmonter les défis actuels à la surveillance des oiseaux dans la forêt boréale, il convient de consacrer des efforts importants à l'intégration et à la mise à disposition des données existantes. Le renforcement des efforts d'enquête portant sur des espèces multiples jouera également un rôle important. La mise en oeuvre de programmes d'échantillonnage équilibrés avec un modèle à panel rotatif pourrait équilibrer les compromis entre réplication spatiale ou temporelle moyennant un coût raisonnable. L'amélioration de l'accès aux co-variables environnementales explicites sur le plan spatial et temporel permettrait en outre d'élaborer des modèles de population mécaniques qui amélioreront notre compréhension de la dynamique des populations d'oiseaux migrateurs. Enfin, compte tenu du fait qu'il faut parfois de nombreuses décennies pour que les programmes de surveillance à long terme produisent des tendances fiables en matière de populations et que les priorités des organisations évoluent au fil du temps, nous pensons que des efforts collaboratifs contribueront à assurer la pérennité des nouveaux programmes de surveillance.

Key Words: boreal forest; breeding bird surveys; conservation planning; environmental indicators; population monitoring; population trend

\section{INTRODUCTION}

The North American boreal forest is home to $>300$ avian species and hosts 3-5 billion birds during the breeding season, comprising a mixture of resident, short-distance, and long-distance migrants (Niemi et al. 1998, Wells and Blancher 2011, North American Bird Conservation Initiative 2016). The status of bird populations in the boreal forest is of particular interest because the velocity of climate change in the boreal forest is expected to be among the highest globally, and species may not be able to adapt to shifting bioclimatic niches, particularly if faced with multiple anthropogenic perturbations (Loarie et al. 2009, Settele et al. 2014, Virkkala 2016). Moreover, the boreal forest will become increasingly important for Nearctic birds as the region gains new species shifting north in response to climate change (Langham et al. 2015). Although logging and other large-scale anthropogenic disturbances began in the North American boreal forest later than in more southerly areas, the recent, rapid expansion of mechanized logging, oil and gas exploration, and other forms of disturbance have now likely driven large portions of the boreal forest outside of the range of natural variability in disturbance rates (Cyr et al. 2009, Pickell et al. 2015, but see Guindon et al. 2018).

Little is known about how current anthropogenic activity in the boreal region might affect bird populations or natural disturbance regimes over the long term (Venier et al. 2014, Holopainen et al. 2015, Webster et al.2015). Given that the boreal forest is a dynamic landscape driven by natural perturbations such as forest fires and insect infestations, it has been hypothesized that emulating the past disturbance regimes of forested landscapes may help maintain resilient avian communities (Drever et al. 2006, Whitaker et al. 2008, Cooke and Hannon 2012). However, there have been few tests of how management strategies designed to emulate natural disturbances affect ecological resilience, particularly with respect to avian communities (Van Wilgenburg and Hobson 2008, Kardynal et al. 2009, Zimmerling et al. 2017). Recent reviews suggest that several boreal species, many of which are long-distance migrants, are steeply declining and that monitoring efforts should be expanded in this region to identify the species most at risk and the primary drivers of population change (North American Bird Conservation Initiative 2016, Rosenberg et al. 2016, Handel and Sauer 2017, Hudson et al. 2017).

Ongoing monitoring efforts in the boreal region range from targeted programs to omnibus surveillance programs (Nichols and Williams 2006). Targeted programs favor causal inference through focused experimental design, whereas surveillance programs favor broader standardized protocols to monitor multiple species across different ecological scales to detect pronounced population fluctuations and provide ad hoc ecological insights (Nichols and Williams 2006, Wintle et al. 2010). Despite their greater variability, and thus lesser power, surveillance programs are generally used first as a source of information about a given population's trajectory, which we define as the pattern of change in population size (Fig. 1). However, population trends, defined as rate of change over a specific time period (e.g., $\%$ annual change), are preferred by many agencies and initiatives to assess population status, and conservation actions are often enacted based on thresholds in population trend (Fewster et al. 2000, Dunn 2002, Butchart et al. 2004, Connors et al. 2014). Targeted monitoring programs are often touted as superior to omnibus surveillance programs (Nichols and Williams 2006), though because of the greater effort and structure required these surveys tend to be limited to a single species or population that is declining or has a restricted distribution. Targeted monitoring programs are also often limited in spatial and temporal scale and data volume (LaSorte et al. 2018). Many large-scale monitoring programs nonetheless fall under the umbrella of reactive management, in which managers do not take action as long as the population of interest remains between some arbitrary thresholds (Nichols and Williams 2006). Partially structured and unstructured surveillance programs are advantageous in that they provide copious information on the status of many species across broad spatial and temporal scales (LaSorte et al. 2018), but on their own they generally offer little insight when it comes to implementing management strategies to stem a decline (but see Burton et al. 2014). Surveillance programs can thus serve to trigger research on specific demographic parameters or aspects of the annual cycle to guide appropriate conservation actions for declining populations. 
Fig. 1. Simulated population trend. The black line and dots represent the observed abundance of the population; the blue dotted line represents the modeled response of the population to a cyclic climatic variable, which is the main population driver; and the red dashed line represents the estimated population trend via a Poisson regression. In this case, the red line would represent the "signal," and the deviations from it would represent the process "noise." Much of the interannual variation in abundance could be explained by the climatic driver.

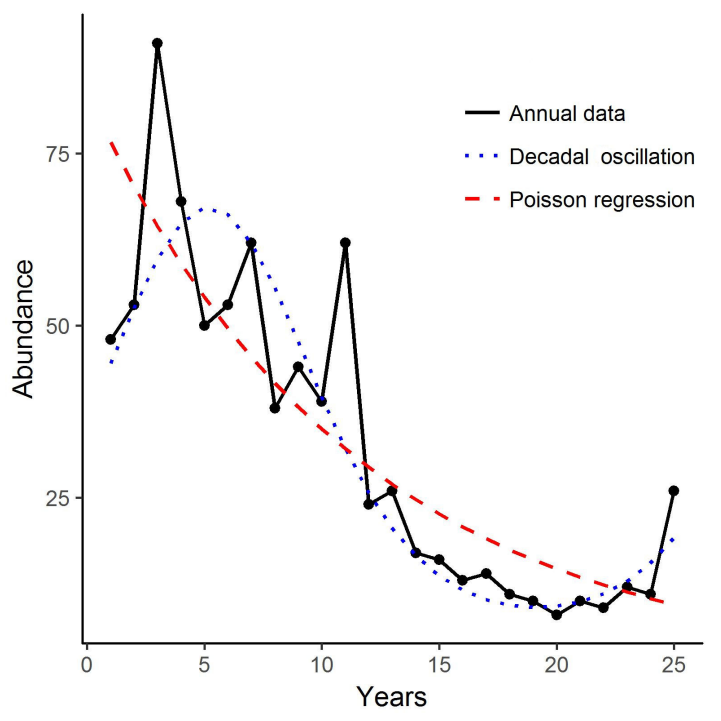

In some cases, monitoring is needed only to acquire the basic biological understanding of the system before developing active management decisions or conservation targets (Nichols and Williams 2006). To be more effective, however, monitoring is often embedded into a larger adaptive management framework where the data gathered through monitoring are explicitly analyzed with quantitative models, which in turn provide the necessary feedback loop to complete the cycle of planning, implementation, and evaluation of conservation and management actions (Nichols and Williams 2006). In an adaptive management framework, the need for immediate action is combined with a plan for learning, and conservation and management activities are altered to reflect new information obtained through monitoring and other activities (Williams et al. 2007, Williams and Brown 2016). In this framework, monitoring is the key component that allows managers to assess the degree to which conservation objectives are being met or to evaluate bird responses to the last management decision (Williams et al. 2007, Lyons et al. 2008).

Substantial effort has been dedicated to developing population monitoring programs in North America (Table 1). Some programs, such as the North American Breeding Bird Survey (BBS; Sauer et al. 1997; Fig. 2), the Waterfowl Breeding Population and Habitat Survey (WBPHS; Smith 1995; Fig. 2), and the National Audubon Society's Christmas Bird Count (CBC; Soykan et al. 2016; Fig. 2), seek to monitor population
Fig. 2. Geographic coverage of the major bird surveys in North America. Starting coordinates for all routes of the Breeding Bird Survey that were conducted in spring 2017 (top left); survey strata and transects of the Waterfowl Breeding Population and Habitat Survey (WBPHS) as of 2017 (top right; Traditional Survey Area in red and Eastern Survey Area in blue); centroids of the circles for the Audubon Christmas Bird Count (CBC) as of 2017 (bottom left); and Boreal Avian Modelling Project (BAM) point-count survey locations in North America as of June 2014 (top; Barker et al. 2015). The boreal and hemiboreal regions (Brandt 2009) are depicted in green for reference.
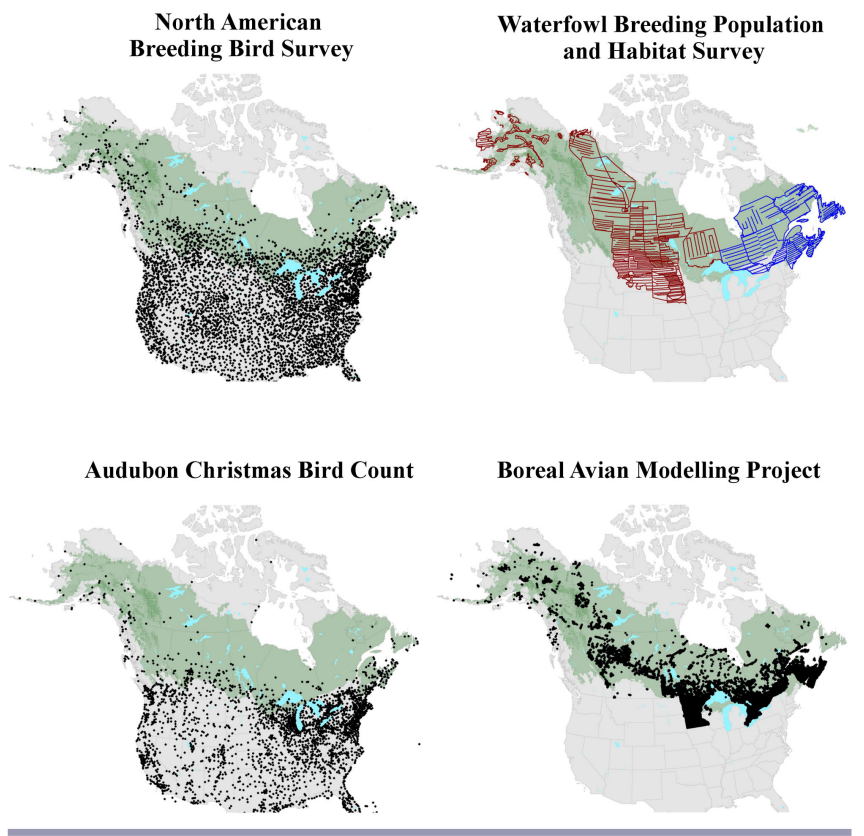

status and trends across broad spatial scales. Others, such as the Monitoring Avian Productivity and Survivorship (MAPS; Albert et al. 2016; Fig. 3; http://www.VitalRatesOfNorthAmericanLandbirds. org) program run by the Institute for Bird Populations, aspire to provide inferences about population demographic processes at similarly large spatial scales; however, the effort required to obtain demographic data across broad regions is great, resulting in small and unrepresentative samples for many regions and species of interest (Miller et al. 2019). These efforts have not been fully extended in the boreal forest, and our ability to monitor populations in this region remains limited. Existing long-term monitoring programs in the boreal forest are generally confined to the southern road-accessible regions, where human populations and activities are highest, leaving many boreal bird species' population trends poorly estimated and likely biased (Blancher et al. 2009, Matsuoka et al. 2011, Machtans et al. 2014, Rosenberg et al. 2017). This limited coverage in northern regions results in uncertainty as to whether trajectories detected in southern regions apply to more northerly regions where both natural processes (e.g., climate change) and anthropogenic disturbance rates may differ widely (Machtans et al. 2014, Handel and Sauer 2017, Van Wilgenburg et al. 2018). Monitoring is also 
Table 1. List of the most comprehensive bird monitoring programs in North America, including the groups of birds monitored, the type of monitoring carried out, the year the program was established, and the proportion of the monitoring effort allocated by the program to the boreal forest.

\begin{tabular}{|c|c|c|c|c|c|}
\hline Survey & $\begin{array}{l}\text { Species } \\
\text { Group }\end{array}$ & $\begin{array}{l}\text { Type of } \\
\text { Monitoring }\end{array}$ & Established & $\begin{array}{l}\% \text { Boreal } \\
\text { Forest }\end{array}$ & $\begin{array}{l}\text { Primary Reference for the } \\
\text { Survey }\end{array}$ \\
\hline Christmas Bird Count (CBC) & All & Surveillance & 1901 & 12.00 & Soykan et al. (2016) \\
\hline North American Breeding Bird Survey (BBS) & Landbirds & Surveillance & 1966 & 19.62 & Sauer et al. (1997) \\
\hline Monitoring Avian Productivity and Survivorship (MAPS) & Waterbirds & Targeted & 1995 & 10.53 & Albert et al. (2016) \\
\hline $\begin{array}{l}\text { Waterfowl Breeding Population and Habitat Survey } \\
\text { (WBPHS; Traditional Survey Area) }\end{array}$ & Waterfowl & Surveillance & 1955 & 57.20 & Smith et al. (1995) \\
\hline $\begin{array}{l}\text { Waterfowl Breeding Population and Habitat Survey } \\
\text { (WBPHS; Eastern Survey Area-Airplane) }\end{array}$ & Waterfowl & Surveillance & 1990 & 88.50 & Zimmerman et al. (2012) \\
\hline International Shorebird Survey (ISS) & Shorebirds & Surveillance & 1974 & 12.15 & Howe et al. (1989) \\
\hline $\begin{array}{l}\text { Program for Regional and International Shorebird } \\
\text { Monitoring (PRISM) }\end{array}$ & Shorebirds & Surveillance & 2002 & 2.10 & Bart et al. (2005) \\
\hline
\end{tabular}

Fig. 3. Geographic coordinates of the banding stations that have been operated between 1989 and 2017 for the Monitoring Avian Productivity and Survivorship program (top) and geographic coordinates of the banding stations that have been operated to band ducks between 1970 and 2015 (bottom). The boreal and hemiboreal regions (Brandt 2009) are depicted in green for reference.

\section{Monitoring Avian Productivity and Survivorship}

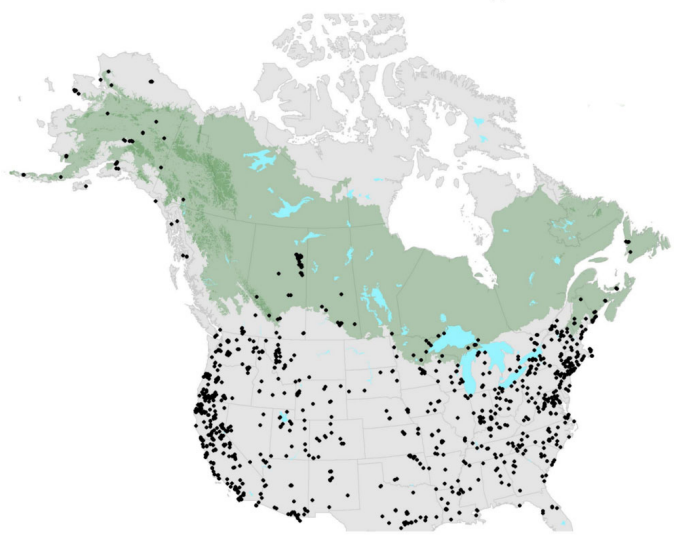

\section{Waterfowl Banding Stations}

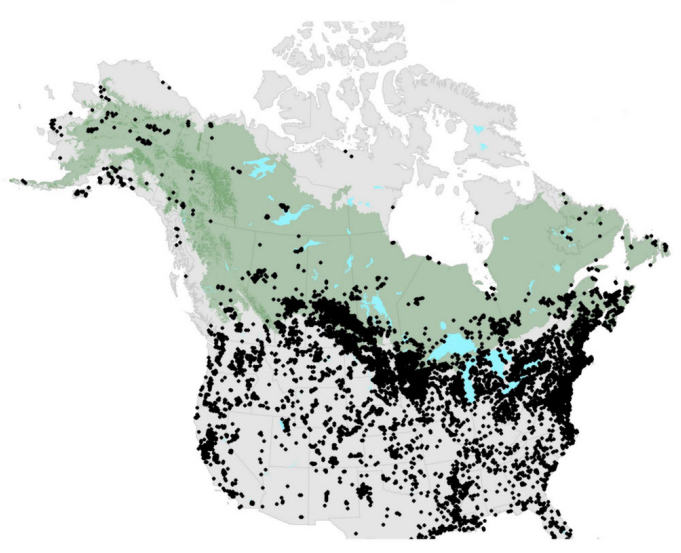

unequal among the different bird groups, and the information on shorebirds (Fig. 4), waterbirds, birds of prey, and nocturnal species is particularly limited (Kirk and Hyslop 1998, Sinclair et al. 2004, Hudson et al. 2017, Sauer et al. 2017b).

Fig. 4. Geographic coordinates of the plots for the Program for Regional and International Shorebird Monitoring (PRISM) Arctic surveys (square dots) and migration monitoring surveys (round dots; include the International Shorebird Survey, the Atlantic Canada Shorebird Survey, and the Ontario Shorebird Survey).

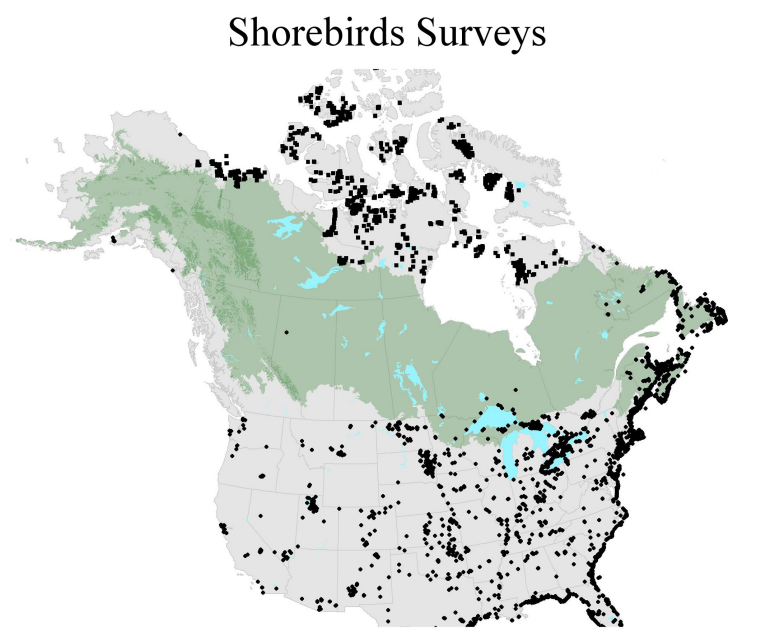

Spatial and temporal gaps in the coverage of the long-term programs may be filled by aggregating data across many finer scale, independent studies, but doing so requires careful consideration to reconcile variations in survey protocols (Matsuoka et al. 2014, Barker et al. 2015). Different monitoring programs that have been conducted in the boreal forest are being integrated by the Boreal Avian Modelling Project (BAM; http:// www.borealbirds.ca/; Fig. 2). Government agencies have also continued to examine new methods that complement the coverage provided by existing programs, such as the deployment of automated recording units (ARUs) or the development of new 
survey methods, but the process of integrating data from existing and new programs is an open area of research (Venier et al. 2012a, Rempel et al. 2013, Pacifici et al. 2017, Pankratz et al. 2017, Thompson et al. 2017, Vold et al. 2017). The emergence of citizen data collection programs such as eBird, a citizen science data repository for bird sightings (http://www.ebird.org; Fig. 5), and iNaturalist (https://www.inaturalist.org/) can provide monitoring data from across broad spatial scales. However, their reliance on volunteers leads to strong spatial bias favoring densely populated locations (Fletcher et al. 2019), and these programs are thus of limited value in remote areas such as the boreal forest. Given the growing gap between the extent of current field studies in the boreal forest and the extent of emerging conservation issues because of resource extraction and climate change, there is an urgent need to develop more effective monitoring in the boreal forest (Cumming et al. 2010).

Fig. 5. Available checklists from the eBird database in the boreal forest as of August 2018.

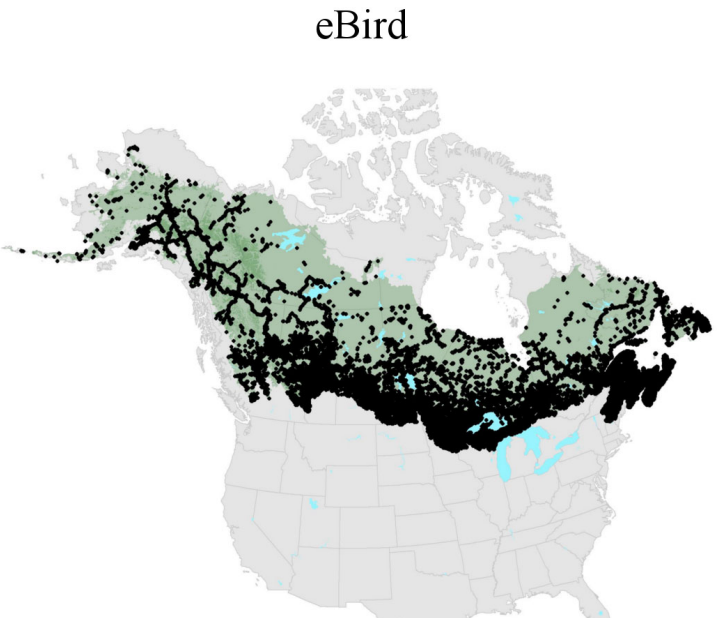

Inferences drawn from population trends in boreal ecosystems will be most realistic and effective in informing conservation efforts when complexities related to detecting and understanding population trends and trajectories are considered. Identifying spatial variability in population drivers across a range of environmental conditions would provide insight about speciesspecific responses to future changes in climate and land use or changes in management strategies (Roy et al. 2016, Hudson et al. 2017). Knowledge developed from working at expanded spatial and temporal scales and from studying the interactive effects of the many drivers that influence population-level processes would contribute to better informed decision making for the boreal region. Given the current lack of coverage of monitoring programs for bird populations in the boreal forest and the need to step up efforts in this biome, we did a review of (1) the main challenges associated with monitoring avian populations in the boreal forest and (2) the available tools for population monitoring and their applications, so that we can help (3) identify future directions to overcome current challenges in monitoring bird populations in the boreal forest. We hope that this review will help guide the development of monitoring and conservation efforts in the future in this very important biome.

\section{CHALLENGES IN MONITORING POPULATIONS WITHIN THE BOREAL FOREST}

\section{Defining populations}

To discuss population trajectories and trends, we must first delineate populations for each species considered. Ecological theory distinguishes populations at two spatial scales: local populations and natural populations (Andrewartha and Birch 1954). The local population constitutes the basic unit of metapopulation theory, and these populations are driven primarily by immigration and emigration dynamics (Hanski 1999, Camus and De Ciencias 2002). The redistribution of birds among local populations can occur independently of the birth and death processes and can obscure the long-term trend of the metapopulation. By contrast, natural population dynamics are driven mainly by birth and death processes rather than a redistribution process (Berryman 2002, Rushing et al. 2016b). The natural populations act as distinct demographic units and therefore form the fundamental unit for understanding ecological processes (Rushing et al. 2016b). Consequently, discussions of population trends or trajectories are implicitly, if not explicitly, referring to natural populations, because at the local scale it becomes difficult to interpret whether a trend is because of movement instead of a change in reproduction or survival rates. Delineating a species' natural populations is complicated and takes substantial time and effort. For example, Rushing et al. (2016b) delineated natural Wood Thrush (Hylocichla mustelina) populations on the basis of shared demographic rates by using trend and abundance data from the BBS (Sauer et al. 2017a), which were verified by an independent demographic data set from the program (DeSante et al. 1999, 2015). However, there are currently not enough data available to fit comparative population models for most boreal species. Delineation of natural populations for a species is often not practical until a broad and persistent decline has been detected. For multispecies monitoring programs, thresholds of decline can be set to trigger further research on population structuring in a species, which can then be investigated with a variety of tools such as genetics, stable isotopes, capture-mark-recapture (CMR) programs, and tracking devices.

Applying the concept of natural populations to conservation is challenging because the spatial scales of identified populations generally do not align with the administrative boundaries within which conservation and management decisions are made. Existing large-scale surveys such as the BBS and CBC generally use administrative boundaries (e.g., states/provinces), ecoregions, or designated regions such as Bird Conservation Regions or Landscape Conservation Cooperatives as proxies for population boundaries (Soykan et al. 2016, Sauer et al. 2017a). Although using these predefined administrative boundaries for population analysis offers some flexibility and allows inferences on populations at multiple spatial and temporal scales, it comes at a cost. A stable or weakly positive/negative population trend in a unit such as a Bird Conservation Region could result if the region includes two natural populations undergoing both positive and negative population trajectories that cancel one another out (Fig. 6). Other variations might include a combination of stable and declining natural populations in a region, which would lead to an overall regional or range-wide negative trend prompting 
conservation action for the stable population as well. This has important implications for management because conservation and management efforts to reverse population declines in species that are undergoing declines range-wide but exhibit a mix of declining and stable or increasing trends locally (e.g., many aerial insectivores; Michel et al. 2016) should be targeted at declining local populations.

Fig. 6. Estimated abundance of two populations (red and blue) with different population trajectories, trends, and stochastic processes. For both populations, the dark line represents the observed process, the shaded area includes the $95 \%$ confidence interval of the annual estimates, and the dashed line represents the estimated population trend. The orange line represents a situation in which half $(50 \%)$ of the surveys are from each population and the results are analyzed as a single population.

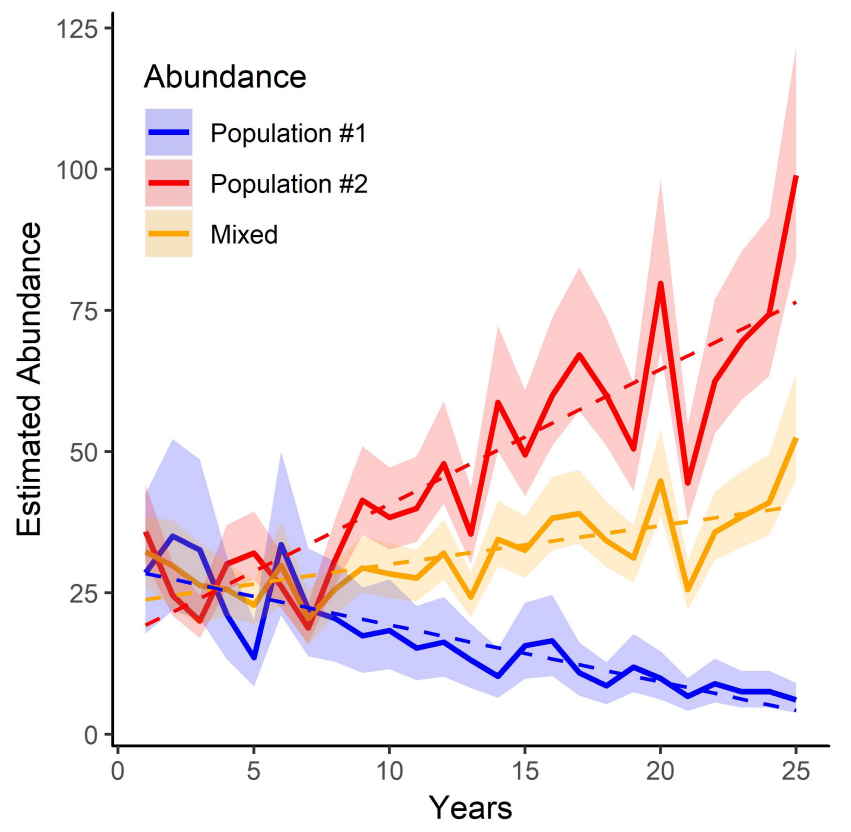

An alternative to identifying natural populations is to define a "population" of interest in terms of the spatial extent of the anticipated drivers of change. This approach may reduce the likelihood of including mixed trajectories within a single analysis. Unfortunately, the spatial extent of the driver of interest is not always known; co-occurring drivers may have very different spatial scales, e.g., local habitat losses and regional climatic changes; and populations drivers can be nonstationary and change though time.

\section{Understanding population processes}

Monitoring data from local or large-scale monitoring programs are often used to develop a form of predictive management in which a few key drivers of the population are identified to improve forecasts of the population trajectory. For this review, we define the "signal" as the overall tendency of the population trajectory, which is likely a function of multiple drivers (Fig. 1). Choosing the correct population drivers for intervention is important because management actions can affect populations for several years and constrain future conservation actions (Connors et al. 2014, d'Eon-Eggertson et al. 2015, Keith et al. 2015). It is also important to distinguish between longer term target trajectories of interest and variations on those trajectories because of nontarget drivers or sources of variation. The "target trend" is the rate of change because of a driver of interest over a specific period. A "nontarget trend" is the rate of change because of drivers that are not of specific interest and could be hidden as a component of process "noise" if not identified. Process "noise" represents interannual deviations from the population's current trajectory caused by stochastic variations in birth and death rates or immigration and emigration (Lande et al. 2003, Connors et al. 2014). For example, in the boreal forest, spruce budworm (Choristoneura sp.) outbreaks increase food availability for many forest landbirds (Venier and Holmes 2010). In the case of known budworm specialists such as the Bay-breasted Warbler (Setophaga castanea), the trajectory of the population is correlated with spruce budworm outbreaks (Drever et al. 2018). To estimate the true impact of forest management practices on the Bay-breasted Warbler population, it is necessary to control for or isolate the nontarget, often cyclical population trajectory attributable to budworm outbreaks.

It is seldom possible to clearly disentangle the signal from the noise because of the lack of data and life history information available for most boreal species. The factors that influence population dynamics are also strongly species dependent, with extensive local and regional variability in drivers within a single species, resulting in highly heterogeneous responses of avian populations across the boreal region and across taxa. Within a single species, the amplitude of population cycles can be habitat dependent (Rodenhouse et al. 1997, Zimmerman et al. 2009). The combination of climate, habitat quality, and the capacity of a species for dispersal will determine the amount of synchrony among different populations, which in turn determines the resilience of the species toward perturbations (i.e., the Moran effect; Hansen et al. 2013, Koenig and Liebhold 2016). Across species, fire regimes can drive songbird population dynamics (Morissette et al. 2002, Hannon and Drapeau 2005) but are unlikely to play much of a role in waterfowl population dynamics (Lewis et al. 2016). Aerial insectivorous birds simultaneously show strong spatial synchrony in population fluctuations within species, and synchronous change points in population trends across species, but species-specific variation in population fluctuations in regions where they coexist (Smith et al. 2015, Michel et al. 2016).

Our ability to test hypotheses about causes of population fluctuations can also be hampered by an inability to attribute clear effects to specific drivers. Birds are simultaneously exposed to numerous factors throughout the annual cycle that could influence population processes, including climate, weather, habitat loss and fragmentation, pollutants, invasive species, and anthropogenic landscape changes (Calvert et al. 2013, North American Bird Conservation Initiative 2016). Even when measurements of such variables are available, causal relationships may be difficult to identify because of correlation among potential drivers (Venier et al. 2014, Hefley et al. 2016). Few studies have explicitly examined interactions among anthropogenic factors, and it is unclear if threshold effects because of widespread and sustained loss of habitat limit the long-term resiliency of 
Table 2. List of potential key drivers of change in boreal bird populations, the vital rates affected, the primary species groups that can be affected by the drivers, and the spatial scales at which the drivers typically operate. AMO, Atlantic Multidecadal Oscillation; ENSO, El Niño Southern Oscillation; NAO, North Atlantic Oscillation.

\begin{tabular}{|c|c|c|c|c|}
\hline Category & Driver & Vital Rates & Species Group & Scale \\
\hline \multirow[t]{5}{*}{ Climate } & Climatic dipoles (e.g., ENSO, NAO, AMO) & Reproductive success, survival & All & Continental \\
\hline & Directional climate change & Reproductive success, survival & All & Continental \\
\hline & Extreme weather events & Survival & All & $\begin{array}{l}\text { Continental, regional, } \\
\text { and local }\end{array}$ \\
\hline & Oceanic regime shifts & Reproductive success, survival & $\begin{array}{l}\text { Ducks, geese, } \\
\text { waterbirds }\end{array}$ & Continental \\
\hline & Temperature and precipitation fluctuations & Reproductive success, survival & All & Regional and local \\
\hline \multirow[t]{5}{*}{ Community changes } & Invasive species & Reproductive success, survival & All & Regional and local \\
\hline & Infectious disease & Survival & All & Regional and local \\
\hline & Nutrient cycling & Reproductive success & All & Regional and local \\
\hline & Predator abundance & Reproductive success, survival & All & Regional and local \\
\hline & $\begin{array}{l}\text { Prey abundance and phenology (insects, } \\
\text { microtines, hares, etc.) }\end{array}$ & Reproductive success, survival & All & Regional and local \\
\hline \multirow[t]{2}{*}{ Landscape changes } & Fire regime changes & Reproductive success, survival & All & Regional and local \\
\hline & $\begin{array}{l}\text { Habitat loss, fragmentation, and } \\
\text { degradation }\end{array}$ & Reproductive success, survival & All & Regional and local \\
\hline \multirow{4}{*}{$\begin{array}{l}\text { Anthropogenic } \\
\text { changes }\end{array}$} & Contaminants & Reproductive success, survival & All & Regional and local \\
\hline & $\begin{array}{l}\text { Habitat loss, fragmentation, and } \\
\text { degradation }\end{array}$ & Reproductive success, survival & All & Regional and local \\
\hline & Hunting & Survival & All & $\begin{array}{l}\text { Continental, regional, } \\
\text { and local }\end{array}$ \\
\hline & Pesticides & Reproductive success, survival & $\begin{array}{l}\text { Granivores, } \\
\text { insectivores }\end{array}$ & Regional and local \\
\hline
\end{tabular}

populations (Cox et al. 2013, Lewis et al. 2016, Mahon et al. 2019). Although the mechanisms are poorly understood, climate and land-use change may have interactive rather than additive effects, complicating both our understanding of population drivers and our ability to manage for them (Ludwig 2007, Oliver and Morecroft 2014, Terraube et al. 2017).

Population drivers are often hierarchically structured and influence populations at multiple scales (Table 2; Flesch and Steidl 2010). Drivers also act across a range of temporal scales, often concurrently, and may produce lagged responses at the population level. For example, climatic episodes such as the El Niño Southern Oscillation influence weather patterns over broad spatial and temporal scales (Stenseth et al. 2003) and have been shown to affect demographic rates (Nott et al. 2002, Lamanna et al. 2012), long-term population trajectories, and resultant species distributions (Luoto et al. 2007, Bateman et al. 2016). At the same time, local extreme weather events and short-term fluctuations in rainfall and temperature can have both long-term and short-term effects on the trajectories of bird populations, often most pronounced at distributional margins (Moreno and Møller 2011, Bateman et al. 2016). Similarly, the North Atlantic Oscillation (NAO) influences migratory patterns of birds in boreal forests of Europe (Rainio et al. 2006), and dipole oscillations are associated with Pine Siskin (Spinus pinus) irruptions in North American boreal forests (Strong et al. 2015). However, Rusty Blackbird (Euphagus carolinus) populations exhibit a 6-yr lagged response to the NAO (McClure et al. 2012), and many North American bird species exhibit a 6- to 36-mo lag to climatic variables (Bateman et al. 2016). Other factors including local weather, habitat loss, and anthropogenic disturbances may have short- to mid-term effects. Birds are susceptible to "black swan" events, in which a highly improbable population crash occurs because of extreme weather events, habitat alteration, or a change in the local community structure (Anderson et al. 2017). For example, a significant population decline observed in eastern Canada for the Chimney Swift (Chaetura pelagica) was linked to a significant mortality event experienced during migration through the pathway of Hurricane Wilma in 2005 (Dionne et al. 2008).

\section{Full annual life-cycle processes}

Processes outside of the boreal region or outside of the breeding period of the annual life cycle (i.e., cross-seasonal effects) also influence the long-term trends of migratory boreal-breeding bird populations. For example, temporal patterns in the loss and degradation of wintering habitat, i.e., bottomland hardwood forest, in the southern United States are consistent with patterns of population decline for Rusty Blackbirds (Greenberg et al. 2011). Similarly, Wood Thrush populations in eastern hardwood and boreal forests are more limited by climate and habitat loss on the nonbreeding grounds than by conditions on the breeding grounds (Rushing et al. 2016a). The conditions on the wintering grounds can also have transient effects on abundance. High spring temperatures in southern locations can prolong spring migration and lead to increased numbers of waterfowl in boreal regions (Johnson and Grier 1988, Pöysä and Väänänen 2014). High plant productivity on wintering grounds has been linked to increases in the following year's breeding population of American Redstarts (Setophaga ruticilla) within eastern North America (Wilson et al. 2011). Conditions on the wintering grounds also have carryover effects on arrival date and reproductive success of boreal-breeding birds such as the Wood Thrush (McKinnon et al. 2015) and 
Kirtland's Warbler (Setophaga kirtlandii; Rockwell et al. 2012). However, the lack of knowledge for most boreal bird species regarding the connectivity between breeding and wintering grounds hampers assessments of cross-seasonal effects. Recent efforts connecting breeding and wintering populations using high-resolution genetic markers (Ruegg et al. 2014) and geolocators (Hallworth et al. 2015, Hobson et al. 2015) have also revealed that breeding populations frequently included individuals that overwintered hundreds of kilometers apart, often in different ecoregions. The dispersion of breeding bird populations into disjunct nonbreeding areas will add another layer of complexity to population monitoring and trend analysis (Rushing et al. 2016a, Taylor and Stutchbury 2016, Cohen et al. 2018) and could also complicate the allocation of conservation efforts (Rushing et al. 2016a).

\section{Taking observation error into account}

An important challenge associated with the development of any monitoring strategy is that the measurements will be imperfect and that the error associated with the measurements can cloud the inference drawn from the data. Ecological inference is improved when process noise can be distinguished from observation error (Clark and Bjørnstad 2004, Connors et al. 2014). Observation error arises from multiple sources and, similar to population processes, may have both systematic and stochastic components. Systematic biases can arise from factors like variation in detection among and within species amid different habitats (Schieck 1997, Pacifici et al. 2008), directional changes in observer abilities over time such as declining hearing (Farmer et al. 2014), seasonal variation in detectability or spatial variation in observer skill (Johnston et al. 2018), improved confidence and training (Kendall et al. 1996, Sauer et al. 1994, Tingley and Beissinger 2013), changes in microphone sensitivity for ARUs (Turgeon et al. 2017), or sampling protocols failing to track the advancement of the breeding season because of climate change (McClure et al. 2011). The systematic and stochastic components can be modeled to reduce their impacts on population inferences when surveys are appropriately designed (Matsuoka et al. 2014) and relevant covariates are recorded (Sauer et al. 1994, Pacifici et al. 2008, Farmer et al. 2014, Johnston et al. 2018).

\section{AVAILABLE STATISTICAL TOOLS}

\section{Abundance surveys}

The tools used to analyze the trends and trajectories of a bird population will be dependent on the types of data being collected. The most straightforward approaches involve estimating bird abundance, density (abundance per unit area), or indices of relative abundance through a count-based survey. The measurements are generally extrapolated to estimate the overall population size for a given survey area. Depending on the goals of the survey and how the data were collected spatially, abundance data collected over a time period can be analyzed either as a single population or as multiple populations in a multivariate framework. For single-population models, either each sampling site is analyzed independently or all of the sampling sites are assumed to share a common set of parameters governing abundance. For analysis of multiple populations, temporal variation in abundance is modeled simultaneously for different components of the population to accommodate spatial heterogeneity. Both types of analysis allow modeling approaches that can implicitly or explicitly address observation error, such as through multilevel models.

\section{Single-population models}

There are many methods available to analyze changes in abundance for a single population, but they can be broadly divided into "index-based" or "inference-based" methods, depending on how they control for systematic bias or sampling error arising from the imperfect detection of birds during counts (Lancia et al. 2005, Nichols et al. 2009). Index-based analyses rely on standardized field methods and statistical covariates to control for the most likely sources of variation in detectability and to generate unbiased estimates of relative abundance. The BBS, for example, uses strict standardizations on survey timing, weather conditions, and observer quality and commitment, as well as statistical controls on both within- and among-observer variation in detectability to generate unbiased estimates of trends in relative abundance over time. The unmatched spatial extent and temporal span of programs like the BBS and the $\mathrm{CBC}(>50$ and $>100 \mathrm{yr}$, respectively) are partly a function of the simplicity and efficiency of their field methods, which are designed to estimate relative abundance without explicitly modeling imperfect detection.

Given that boreal bird populations change at multiple, processdependent timescales, the optimal statistical method to model a particular population trend will depend on the relevant timescale. The available models for such analysis include, in ascending order of complexity, the generalized linear model (GLM), generalized additive model (GAM), autoregressive models, and wavelet analysis methods. These models can be developed in either frequentist or Bayesian frameworks (Bolker 2008, Royle and Dorazio 2008, Woods 2017). Long-term, monotonic population increases or decreases are efficiently modeled using some form of generalized linear regression models, such as Poisson or negative binomial regressions. Because regression models estimate a single slope parameter for the entire specific time period, they efficiently estimate average rates of change, even for relatively sparse data sets. These regressions also allow the inclusion of potential population drivers in a straightforward fashion, via covariates. These models can also accommodate some departure from linearity by including polynomials if the user has an idea of the functional form of the relationship. They can also incorporate random year effects to account for stochastic interannual variation around an underlying trend (Sauer and Link 2011).

Modeling population cycles or annual fluctuations requires more complex models. Nonparametric options, such as GAM and LOESS (locally estimated scatterplot smoothing) curve fitting, are particularly useful for delineating the form of trajectories without the need for prior assumptions about the functional form of the response (Fewster et al. 2000, Knape 2016). Like GLMs, GAMs readily allow the inclusion of population drivers while also accommodating nonlinear relationships, which can be a huge advantage. GAMs can also be used to model ecological covariates with relatively smooth multiyear cycles, such as those linked to decadal climate oscillations (e.g., Macias Fauria and Johnson 2008) or periodic insect outbreaks. Autoregressive models can be used to model autocorrelated processes, such as irruptions of seed-eating birds relative to high production of seed cone crops (Koenig and Knops 2001), whereas wavelet analysis can be useful 
for detecting autoregressive patterns or cycles in the data (Barraquand et al. 2017). The strength of these models resides in their ability to identify lagged population processes.

There are many inference-based methodologies that explicitly estimate detection probabilities to model true abundance separate from the observation process. These state-space models acknowledge that the quantities in the trajectory are functions of unknown true population sizes and isolate the observation error from the population process, which can be advantageous (Clark and Bjørnstad 2004). There are multiple approaches to estimating detection probability and abundance simultaneously, including distance sampling, the double-observer approach, time-removal models, N-mixture models relying on temporal and/or spatial repeats, and combinations of these methods (Nichols et al. 2000b, Buckland et al. 2001, Farnsworth et al. 2002, 2005, Royle 2004; but see recent discussion of the robustness and identifiability of N-mixture models in Barker et al. [2018], Kéry [2018], and Link et al. [2018]).

The recent proliferation of statistical approaches, which typically require a specific field protocol or sampling regime, provides a wide range of options that could be applied to boreal monitoring. However, given the relatively high cost of accessing field locations in boreal locations, single-visit methods are particularly appealing. The approach by Bart and Earnst (2002) provides a middle ground where detection probabilities are directly estimated within a subset of data, providing estimates of detection that can be included as offsets to correct abundance estimates in the rest of the data. This method may provide a flexible approach that is particularly efficient for broadscale boreal monitoring in which data are combined: (1) from multiple individual monitoring programs following different protocols, such as BAM, often leading to different distance and time intervals (Sólymos et al. 2013, Twedt and Wilson 2017), or (2) from human counts and those derived from ARUs (Van Wilgenburg et al. 2017).

It is also possible to construct more complex single-population models such as density-dependent models, although such models are sensitive to observation error (Dennis et al. 2006, Freckleton et al. 2006, Knape and de Valpine 2012, Lebreton and Gimenez 2013). Disentangling the population's process signal from the noise will be particularly difficult and will require additional information regarding the observation error if there are no replications (Dennis et al. 2006, Knape and de Valpine 2012). However, simply assessing the strength of density dependence in a population gives little information on how the population is regulating itself. Thus, density-dependent population models are probably more useful for generating working hypotheses than for use as confirmatory tools (Robinson et al. 2017). Moreover, the estimation of population growth rate parameters and the densitydependent term can still be plagued by identifiability problems even in the best case (Knape 2008, Clark et al. 2010, Lebreton and Gimenez 2013).

\section{Multiple-population models}

Like single-population models, multiple-population models for single species, where trends are modeled simultaneously for distinct spatial units, can account for imperfect detection either explicitly or implicitly via standardization of protocols (Lancia et al. 2005, Nichols et al. 2009). Trajectories from multiple surveys (e.g., BBS routes, $\mathrm{CBC}$ circles) can be estimated conjointly via a hierarchical model. Using hierarchical models offers the advantage of estimating individual parameters by considering them as being part of a group, that is, the set of parameters from each spatial unit for a species (Sauer and Link 2002, Clark et al. 2005). This approach is often described as "borrowing strength" from the ensemble. The conjoint effect can be modeled via a simple random effect in a generalized linear mixed model (GLMM) or can take a more complex form such as state-space models, usually with autoregressive structures to model temporal and/or spatial autocorrelation (Dormann et al. 2007, Zuur et al. 2007). With GLMMs, recent methodologies provide marked improvements that allow the user to account for multiple sources of variation, including observer, stratum, year, and weather effects (Sauer and Link 2011, Ross et al. 2012, Soykan et al. 2016).

Approaches such as dynamic factor analysis can be used to decompose multiple time series, such as count data from a single species across multiple spatial units or multiple populations, to identify underlying common trends representing large-scale population processes (Zuur et al. 2003, Michel et al. 2016). It is also possible to use either geographically weighted regression or spatially varying coefficients (SVC) models to account for relationships that vary over large geographic areas (Finley 2011, Roy et al. 2016). These models can be powerful tools to accommodate either the hierarchical structure or spatial heterogeneity of the population drivers.

There have also been recent developments that relax the strict closure assumption of the original $\mathrm{N}$-mixture model, as well as models that do not require multiple visits if the survey is replicated at multiple locations, though their identifiability has been called into question (Dail and Madsen 2011, Sólymos et al. 2012, Deluca and King 2014, Barker et al. 2018). More complex hierarchical Bayesian models have also been developed for estimating the abundance of multiple populations from point-count or transect data with distance estimation (Oedekoven et al. 2014, Sollman et al. 2015), spatial or temporal replications (Kéry and Royle 2016), and/or removal sampling (Amundson et al. 2014). Additionally, hierarchical models have been used to analyze point-count data jointly from the roadside BBS and more remote roadless areas of Alaska; an additional hierarchical level allows one to test for different population trends between the two strata and increases precision of trend estimates while incorporating different detection parameters associated with each program (Handel and Sauer 2017).

\section{Multiple-species models}

In addition to models for analyzing multivariate repeated counts of a single species, newly developed multispecies abundance models (MSAMs) enable the estimation of abundance for all species in a community while correcting for imperfect detection (Yamaura et al. 2011, Iknayan et al. 2014, Sollmann et al. 2016). MSAMs are $\mathrm{N}$-mixture models that incorporate an additional hierarchical level for species. By jointly estimating parameters for species and communities, MSAMs can borrow strength from wellsurveyed species to produce detection probability and abundance estimates for species with fewer than the 60-80 observations required for traditional distance estimation (Buckland et al. 2001). MSAMs are also able to model the effects of covariates on species and community abundance and diversity (Sollmann et al. 2016). 


\section{Beyond counts: demographics}

Some monitoring programs aim to quantify demographic parameters, such as survival, productivity, or immigration, instead of simply estimating the population size. These programs can offer better insight into the processes governing the population trends and trajectory but are often much more data and effort intensive. A number of models have been developed to estimate demographic parameters and population dynamics from counts of captured individuals or CMR data. Many of these models may be useful for studying fluctuations in boreal bird populations, especially when combined with large-scale, constanteffort mist-netting programs (Saracco et al. 2008). The most common CMR models are generally used to jointly estimate apparent survival and recapture probability (Seber 1970, Pollock 1982, Brownie 1985, Lebreton et al. 1992, Williams et al. 2002). Although survival is typically the demographic rate of interest, these data can also be used to provide indices or estimates of population sizes, productivity, and population growth rates (Arnold 2018, Wilson et al. 2018); estimate demographic contributions to population growth (Pradel 1996, Nichols et al. 2000a, Nichols and Hines 2002); identify spatial and temporal variability in demographic rates (Saracco et al. 2010); and compare results with other sampling protocols (Saracco et al. 2008). For harvested species, it is also possible to estimate the population size via the Lincoln estimator (Lincoln 1930, Alisauskas et al. 2009). Guidelines for the design of CMR studies are beyond our scope but are well documented in the literature (Lindberg 2012, Sollmann et al. 2012).

The main limitation of CMR studies is that they are labor intensive because birds need to be marked and recaptured in sufficient numbers. Recapture rates in particular can be limiting for many species. Consequently, such studies are typically conducted with intensive effort on very small spatial scales. The only formal CMR project for landbirds operating in the boreal forest across a broad spatial extent is the MAPS program (Saracco et al. 2012, Albert et al. 2016). This program coordinates the operation of constant-effort landbird mist-netting and banding stations across North America, including more than 150 stations that have been operated in the boreal zone (Albert et al. 2016). There are also some CMR projects carried out by the U.S. Fish and Wildlife Service and the Canadian Wildlife Service to monitor productivity and survival of waterfowl in the boreal forest, targeting dabbling ducks for the most part (Fig. 3; Blohm et al. 2006). However, there have been only limited local efforts for boreal shorebirds or other resident or migratory bird populations given the logistical difficulties of accessing and working in boreal areas, particularly for less abundant species. Unless collaborative efforts are undertaken, it is unlikely that new broadscale CMR programs will be implemented and maintained across the boreal forest. Results of broadscale, multispecies CMR programs, such as MAPS, can be examined for patterns that might indicate consistent interspecific declines in either productivity or survival associated with boreal breeding grounds. Discovery of such patterns could then trigger more targeted research to identify specific causes of regional declines, particularly for species of concern, regardless of whether their populations are themselves adequately monitored by the CMR program. Finally, as for count and occupancy models, community-level inferences about demographic rates may be obtained via a multispecies modeling approach (Saracco et al. 2018, 2019).

\section{Combining counts and demographics: integrated population models}

Integrated population models (IPMs) combine multiple sources of demographic monitoring data to estimate changes in population size as a function of vital rates (Besbeas et al. 2002). IPMs include a population model that links changes in abundance to vital rates through inclusion of one or more types of demographic monitoring data (Kéry and Schaub 2012). By drawing strength from multiple sources of information about population status, IPMs provide a potentially powerful framework for separating the signal from the noise in fluctuations of boreal bird populations (Besbeas et al. 2002, Schaub and Abadi 2011, Zipkin and Saunders 2018). IPMs are extremely flexible and can accommodate missing data, hierarchical effects, and spatially and temporally structured data with relative ease (Schaub et al. 2007, 2015, Chandler and Clark 2014, Ahrestani et al. 2017, Zipkin and Saunders 2018, Zhao et al. 2019). When demographic data are available for linked breeding and winter populations, full life-cycle IPMs can help link population-level processes operating across the annual cycle (Rushing et al. 2017). IPMs can also be combined with transient life-table response experiments to identify the demographic parameters that have the greatest influence on the population dynamics (Koons et al. 2017) or with population viability analyses to simulate effects of conservation scenarios (Saunders et al. 2018). IPMs have been developed for a wide range of bird species, including songbirds (Oppel et al. 2014, Duarte et al. 2016), raptors (Schaub and Abadi 2011, Altwegg et al. 2014, Tempel et al. 2014), shorebirds (Saunders et al. 2018), and waterfowl (Weegman et al. 2016). However, the use of IPMs in the boreal forest of North America is currently limited to a few dabbling duck species because of the lack of sufficient demographic data for other species (Koons et al. 2017, Robinson et al. 2017).

\section{Power analysis}

Determining the sample sizes and length of time series required to address the question of interest is an important consideration when designing new monitoring programs or reviewing existing ones. The power of a given sampling regime is the probability of detecting an effect of a certain magnitude. The power of a sampling regime can be used to assess its value as a conservation tool. Power to detect a trend or the effect of a suspected population driver depends on the number and distributions of observations, the precision of the estimates, the degree of observation error, and length of the monitoring period (Legg and Nagy 2006, Johnson et al. 2015). because of the limited resources available for bird monitoring, both under- and over-powering can lead to a waste of resources (Ioannidis 2005, Legg and Nagy 2006). Past reviews have shown that at least $15-20$ yr of continuous monitoring is necessary to achieve a high level of statistical power for bird population monitoring, and under some scenarios, such as when there is a long interval between surveys or when longlived species are surveyed, it might take more than $50 \mathrm{yr}$ (Gerrodette 1987, Hatch 2003). Simulation studies should be used to determine the length of trajectories required to detect trends of a given magnitude and to examine potentially important tradeoffs between spatial and temporal replication (Rhodes and Jonzén 2011, Connors et al. 2014). This approach is probably the best way to estimate the power of a sampling scheme relative to the complex models being considered. 


\section{A PATH TO IMPROVED MONITORING OF BOREAL FOREST BIRDS}

\section{Expanded use and availability of existing data}

\section{Bird monitoring data}

Improving the use and availability of existing data sets should be the first step to improve our understanding of migratory bird population trends and trajectories in the boreal forest. Currently, the best available data sets to model the abundance, distribution, habitat relationships, and population trends and trajectories for birds across the boreal forest come from two primary sources: the WBPHS (Smith 1995) and the BAM for passerines (Barker et al. 2015). The WBPHS is a monitoring program that has significant spatial and temporal coverage: 1955-2017 in the Traditional Survey Area and 1990-2017 in the Eastern Survey Area, which together cover most of the boreal region (Fig. 2). The WBPHS is able to obtain such extensive coverage even in the northern boreal region because, as an aerial survey, it is not restricted by the limited road network. However, because of observer limitations during the survey, the observations are summed at the genus level for most sea duck species such as scaup (Aythya spp.) and scoters (Melanitta spp.); the survey is timed with the nesting phenology of early migrants, such as the Mallard (Anas platyrhynchos), and the timing of the WBPHS has been questioned for late-nesting species such as sea ducks (Naugle et al. 2000, Boyd et al. 2015, Schummer et al. 2018). The visual correction factors that account for observations missed during the surveys have not been updated in the boreal forest since the early 1990s (Smith 1995). Although the precision of the population estimates for the dabbling ducks, particularly in the prairies, has never been questioned, there has been a persistent desire to improve waterfowl-survey methodology in the boreal forest, particularly for boreal specialists such as sea ducks and cavity nesters (Mallory et al. 2003, Boyd et al. 2015). This could probably best be achieved through specialized targeted surveys that would be conducted later during the breeding period of late-nesting species.

BAM compiled and standardized $>125,000$ historical point counts, including data from the BBS, over much of the North American boreal forest (1991-2017; Barker et al. 2015). Species distribution models using BAM and WBPHS data and incorporating off-road surveys have been developed for 13 out of 28 duck species (Barker et al. 2014) and for 80 out of the $\sim 300$ passerines species (Stralberg et al. 2015) occurring in the boreal region of North America. However, passerine survey data are far more spatially limited and biased because surveys are conducted from the ground and are concentrated in the southern boreal region where road networks are more extensive (Fig. 2). Because BAM aggregates point-count and point-transect data, the aggregated data set is also phylogenetically biased against species that are not well surveyed by these methods, e.g., birds with large home ranges or limited vocalizations. Many of the data sets represented in the BAM database also have limited temporal replication (Barker et al. 2015), although some constituent programs have been specifically designed with broad spatial and temporal replication (e.g., Alaska Landbird Monitoring Survey; Handel and Sauer 2017). Efforts to increase spatial coverage and temporal replication across the boreal forest within programs contributing to the BAM database would improve our ability to draw inferences about boreal passerine population trends.

Citizen science programs provide useful if incomplete data for understanding boreal bird population status and trends. Though spatially and temporally extensive elsewhere in North America, the BBS, the $\mathrm{CBC}$, and eBird have limited coverage in the northern boreal forest because of their reliance on volunteer observers that survey on foot or by car (Figs. 2 and 5). However, despite their limitations, these programs provide valuable information about boreal bird population trends. CBC data have been used to develop population trends for many boreal-breeding bird species that overwinter within the contiguous United States and southern Canada (Soykan et al. 2016). BBS and CBC data have enabled the development of climate-based species distribution models for hundreds of boreal passerines, waterfowl, and other bird species (Langham et al. 2015). Citizen science data, specifically eBird data, have also been used to develop species distribution models for 117 species of passerines (Schuster et al. 2019). However, they are restricted by the paucity of historical data in the northern boreal forest. As of the last comprehensive assessment of the BBS survey in Canada (Dunn et al. 2005), there were at least 66 species of landbirds ( $21 \%$ of the species) for which trends could not be adequately estimated in large part because of the lack of coverage of the boreal forest. Dunn also pointed out that the trends estimated for some species, such as the Blackpoll Warbler (Setophaga striata), were probably unreliable because the BBS sampled the population only at the fringe of its breeding distribution. Little has changed in the intervening years to ameliorate that situation.

In the absence of repeated counts over a long period of time, few options remain for examining historical variation in avian abundance and correlated drivers. Some data sets are collected annually, and many of these have associated data on habitat or other covariates collected during the original surveys; quantifying changes in the amount and quality of habitat can be used to identify correlates of avian population change (Van Wilgenburg et al. 2018). Unfortunately, few data sets exist with greater temporal replication to allow partitioning of variation attributable to local habitat change versus weather and/or climate and factors outside the breeding grounds. One approach to gain quick insights into changes in species abundance and potential correlates associated with population change would be to revisit historical research sites (Machtans et al. 2007, Van Wilgenburg et al. 2018) and repeat large-scale surveys such as Breeding Bird Atlases to document the impact of land-use change on species presence and abundance (Blancher et al. 2009, Regos et al. 2018). Similar efforts in repeating century-old surveys in California (Tingley et al. 2009, Socolar et al. 2018) and Illinois (Ward et al. 2018) found evidence of dramatic changes in bird distributions and phenology in response to changes in climate and land cover, respectively. Resurveying historical research sites could provide information that is currently lacking; however, biases in the representation of habitat and rates of disturbance are common issues arising from such data and can hamper extrapolation to broader areas (Matsuoka et al. 2011, Wellicome et al. 2014, Van Wilgenburg et al. 2015). The lack of randomization in many historical surveys and/or uncertainty about the inclusion probabilities used to design historical randomized surveys can also hamper extrapolation to the population (Foster et al. 2017); 
however, results from these surveys can provide a point of reference to compare against results from other surveys (Blancher et al. 2009, Regos et al. 2018, Van Wilgenburg et al. 2018).

In the absence of multiple studies with adequate temporal replication, an alternative is to develop methods to combine data sets that contribute broad spatial coverage (such as those in BAM) with those having greater temporal replication (such as the BBS) in joint analyses (Barker et al. 2015, Pacifici et al. 2017). This approach could facilitate the examination of historical changes and interannual fluctuations in the mean abundance of species over coarse spatial or habitat strata. Given that there is limited information on the changes in forest cover and structure at large scales, it remains impossible to assess the wide-ranging cumulative impact of changes in the local vegetation on avian populations. It is currently possible, however, to develop a more comprehensive examination of large-scale impacts of climatic and nonbreedingground factors on variation in boreal populations. Several methodological advances such as the offset approach of Sólymos et al. (2013), hierarchical models (Ross et al. 2012, Handel and Sauer 2017), SVCs (Roy et al. 2016), or multivariate conditional autoregressive models (Pacifici et al. 2017) have already been used with the BAM, BBS, or WBPHS data sets.

\section{Explanatory variables}

Extrapolating results from local studies would be facilitated if habitat data with high spatial and temporal resolution could be obtained for the entire boreal forest. High-quality data such as those available in forest inventories are generally limited to southern portions of the boreal forest (Cosco 2011, Cumming et al. 2015). There has been significant progress in processing satellite imagery time series using cloud-based tools such as Google Earth Engine to produce annual estimates of forest loss and gain (Hansen et al. 2013, Guindon et al. 2018) and to attribute habitat change to natural versus anthropogenic disturbances (Schroeder et al. 2011, Banskota et al. 2014, White et al. 2014). In addition, forest structural characteristics can now also be estimated from remotely sensed data (Simard et al. 2011, Zald et al. 2016), an approach that holds promise for the future. Further research and development of remote-sensing methods, combined with enhanced collection and sharing of ground-based habitat measurements, are needed to enhance our ability to link avian population change with large-scale habitat dynamics.

In addition to a need for high-quality habitat covariates, annual estimates of the abundance and distribution of important prey (e.g., insects, microtines, and hares) would also enhance our ability to predict fluctuations in avian populations. The response of boreal birds to variation in abundance of important insect prey such as spruce budworm (Venier and Holmes 2010, Drever et al. 2018), unless accounted for explicitly, will make it difficult to separate short-term fluctuations in bird populations because of fluctuations in insect populations from long-term trends driven by changes in climate or land cover. Although boreal-wide estimates of density of prey may not currently be available, several proxies may realistically be derived from current data or via satellite monitoring. Venier et al. (2012b) amassed spatial data on defoliation by spruce budworm from historical Canadian Forest Service reports and from data held by various provincial agencies to develop density-dependent stochastic population growth models for several species of boreal birds. Expansion of this effort to greater geographic areas and more species of insects would provide useful information. Alternatively, satellite mapping of insect defoliation (Senf et al. 2017) could provide annual estimates of insect-related population responses at meaningful spatial scales, which could subsequently be used in avian population models in the boreal forest.

\section{Improve data availability}

Survey data are increasingly being used not only to monitor basic population trajectories but also to address key ecological questions that will inform conservation of boreal forest birds. The growing complexity of questions being asked also tends to outpace the amount of explanatory data available to fit the model. Although amassing and standardizing large data sets such as those integrated in BAM will help answer many questions, there are undoubtedly additional, as yet unassimilated data that could partially fill spatial and temporal gaps in sampling. Data sets with survey data and explanatory variables that are not publicly available or that do not even have publicly available metadata to highlight their existence could be invaluable for such efforts. A key step toward facilitating greater use of existing data would be the creation of a publicly accessible archive of metadata, particularly for survey data, and publicizing this accessibility. Lindenmayer et al. (2012) suggested that sharing of metadata should be a condition of funding, and we suggest that it could also be required as part of acquiring research permits or conducting environmental impact assessments. Indeed, providing open access to data sets and associated metadata is now commonly required by many journals and funding sources, including the Natural Sciences and Engineering Research Council of Canada (Innovation, Science and Economic Development Canada 2016), the National Science Foundation (2015), and other U.S. federal agencies. Although incorporation of such "as yet undiscovered" data sets in regional analyses would require developing collaborations and data-sharing agreements, accessible metadata would facilitate these conversations. Extensive work has been done by the BAM to make the results from that program searchable and to make data available for projects approved by the program partners, and any efforts to increase data accessibility could build on this effort (Cumming et al. 2010, Barker et al. 2015).

For explanatory variables, such as fire regime, land cover, or insect abundance and distribution, addressing the issue of ownership of the different data sets and consolidating the different regional products into an integrated database could also greatly enhance population modeling in the boreal forest. The ongoing effort, initiated by various governmental agencies, to move some of the climatic and landscape variables to open source has been invaluable. There is still, however, a lot of work to be done not only to make the data sets available but also to publicize their availability and maintain and update them once they have been published on an open data portal.

\section{Enhancing survey efforts}

The persistent lack of spatial and temporal replication of surveys in vast northerly portions of the boreal forest highlights the need for expanded surveys and monitoring, and we suggest that limited survey coverage is the most important gap to address. Deciding on the most effective design to expand survey coverage is not a clear-cut task because it will depend heavily on the objectives of 
the program, the data already available, and the capability of existing programs to be expanded. Extending existing surveys offers the advantage of reusing a design that has already demonstrated its advantages and limitations. However, many of the existing designs have been developed in the south where accessibility is not an issue. Because of the lack of volunteers and road networks in large portions of the boreal forest and considering the expense involved in professional surveys, there is a need to consider novel, cost-effective sampling designs to address our most pressing data needs. This is particularly true for some groups of species such as grebes, rails, shorebirds, and waders, which have been neglected in the past.

The design of any future surveys should incorporate appropriate randomization and careful documentation of the inclusion probabilities used for strata within the design (Smith et al. 2017). Although randomization is an obvious first step, allocation of sampling effort among strata and obtaining good representation of important covariates and factors that may drive population fluctuations are more complicated steps. One approach would be to employ model-based sampling designs (Gregoire 1998), wherein preliminary models of avian abundance are regressed against factors known or thought to drive avian population fluctuations. Estimates of uncertainty from the parameters, such as the standard errors, in the preliminary models can be used to derive inclusion probabilities for randomized selection of study areas. Specifically, calculating inclusion probabilities that are inversely proportional to uncertainty will place more sampling effort in areas with greater variability and thereby increase precision and sampling efficiency (Tillé and Favre 2005). Such model-based designs, however, are most appropriate for targeted single-species sampling designs because levels of uncertainty in distribution models will vary spatially among species. Preliminary models for key species may provide insights for developing multispecies survey designs that facilitate testing of potentially influential factors within a given region.

If there is a desire to increase the number of species for which we can predict abundance, distribution, trends, and factors influencing fluctuations in population abundance, there is an obvious need to implement omnibus, multispecies surveys. Given the vast expanse of the boreal forest, the spatial design of any new survey should also be given strong consideration. Historical surveys such as the BBS have been designed with sampling that under ideal circumstances is proportional to habitat availability to make the survey representative of the survey area (Droege 1990, Lawler and O'Connor 2004, Van Wilgenburg et al. 2015). However, although representative sampling based on proportional sampling will be efficient for abundant species, it will tend to lead to low power for rare species. Because most boreal species have relatively distinct habitat preferences (Van Wilgenburg et al. 2018), stratifying by physiographic features and major land cover should improve our ability to monitor fluctuations in species abundance and distribution for a greater number of species. Care must be taken, however, not to stratify too finely, because changes in vegetation structure and composition will result in varying sizes of strata over time and thus complicate interpretation of status and trends. Surveys could be further improved by incorporating spatially balanced sampling designs, a form of sampling that seeks to maximize the dispersion of the sites, which tends to increase precision of the estimates by reducing spatial autocorrelation (Grafström et al. 2012, Foster et al. 2017). This design feature may be particularly important for monitoring populations of migratory species, where different populations may show spatially structured variation in migratory connectivity (e.g., chain versus leapfrog migration; Berthold 2001). For such species, fluctuations in population size related to factors on the wintering grounds or along migration routes might not be reflected in the sampling if some form of spatial replication is not implemented.

To balance the trade-offs between spatial versus temporal replication in sampling, rotating panel designs should be investigated. Rotating panel designs partition the study sites into panels, i.e., geographic divisions, with all sites within the same panel being revisited on the same schedule, which can increase geographic coverage across years (Urquhart and Kincaid 1999, Urquhart 2012). Over time, a panel design achieves higher statistical power than surveying a more limited number of sample sites every year (Urquhart and Kincaid 1999, Urquhart 2012). Many panel designs group sites based on spatial location to facilitate field logistics, but this may result in confounding spatial and temporal changes (MacKenzie 2005), which could be especially problematic for monitoring of less common species. Alternatively, one could avoid confounding space and time by assigning study sites to temporal revisit panels without regard to spatial location (Ray et al. 2017). This approach would be logistically challenging in the boreal forest under most scenarios. Although rotating panel designs offer advantages in spatial representation, statistical analysis can become complicated with missing data. Recent statistical advances in dealing with missing observations may reduce this limitation (Clark and Bjørnstad 2004, Hapfelmeier et al. 2014, Nakagawa 2015).

New recording technologies, such as ARUs and unmanned aerial vehicles (drones), also hold great potential to augment humancollected monitoring data, particularly in portions of the boreal forest that are difficult to access (Shonfield and Bayne 2017, Thompson et al. 2017, Vold et al. 2017). ARUs can be programmed to record at specified times and intervals, providing the temporally replicated data needed for models to account for imperfect detection without surveyors needing to make repeat visits. Recent developments using multiple microphones (Mennill et al. 2012) and correction factors developed from paired human surveys (Van Wilgenburg et al. 2017, Vold et al. 2017) or from calibration experiments (Yip et al. 2017) enable data collected by ARUs to be corrected for distance bias. ARUs are expensive and still present some technical challenges, such as archiving and processing the vast quantity of data created by these projects or mitigating microphone degradation over time (Turgeon et al. 2017), but some of these concerns should be alleviated with the emergence of new technologies (Shonfield and Bayne 2017). Drones can be used to extend survey coverage to inaccessible areas and would be particularly useful for larger birds such as waterfowl, which are easy to detect and identify (Hodgson et al. 2016). Quadcopter drones are relatively quiet and can approach birds to within a few tens of meters, enabling identification from imagery (Vas et al. 2015).

The design of the new multispecies surveys should seek to maximize the number and range of species surveyed. However, given that some species and some taxa require specific monitoring 
tools, e.g., callback surveys for secretive marsh birds and raptors and transect surveys for sparsely distributed species, it is obvious that a well-designed boreal avian monitoring strategy will require several complementary surveys that are tailored to specific avian functional groups. In some cases, an adaptive monitoring approach can be implemented when the initial questions have been answered and new questions arise or when new technology enhances field protocols or data analysis and the monitoring framework (Lindenmayer and Likens 2009). It might also be necessary to revisit the monitoring framework of some surveys to ensure that the frequency of monitoring is not being outpaced by the rate of change in the population or its environment; the frequency of monitoring should be altered if change is occurring at a rate that differs from that anticipated (Lindenmayer and Likens 2009, William and Brown 2016). Finally, some species, because of a population decline or some specific concerns such as localized distribution, will undoubtedly require more targeted research. In these cases, the research may need to focus on the species-specific habitat relationships that can be managed to improve reproductive success or survival and stabilize the population trend or even reverse a declining trend.

Monitoring will be more effective if it is embedded within an adaptive management framework where monitoring data are used to evaluate the effectiveness of conservation management actions and plan future actions (Nichols and Williams 2006). However, an adaptive management program can be particularly challenging when implemented to address large-scale ecological phenomena, across multiple land tenures, or to address factors that affect populations at multiple spatial scales (Westgate et al. 2013, William and Brown 2016). Such challenges arise in part because in an adaptive management framework, monitoring programs must be designed and sufficiently resourced to be able to detect changes in populations that derive directly from management or conservation actions (Lindenmayer and Likens 2009, William and Brown 2016). To combine monitoring, management, and conservation actions effectively in the boreal forest, the greatest challenge will likely be to recognize when conservations actions must be explicitly linked through an adaptive management framework and when they can be handled independently (William and Brown 2016).

\section{Expand beyond the boreal forest}

As reviewed in Full annual life-cycle processes, migratory boreal bird populations are affected by processes occurring throughout their life cycle, including on the nonbreeding grounds and in migration corridors (Johnson and Grier 1988, Greenberg et al. 2011, Wilson et al. 2011, Rockwell et al. 2012, Pöysä and Väänänen 2014, McKinnon et al. 2015, Rushing et al. 2016a). Many boreal-breeding bird species winter in Central or South America, where relatively few long-term bird monitoring programs exist. Although it is not a primary objective of a boreal monitoring strategy, increasing monitoring and conservation efforts on the wintering grounds will strengthen the work undertaken in the boreal forest to monitor populations of migratory birds. The main citizen science monitoring programs, such as eBird and the $\mathrm{CBC}$, are present in Central and South America, but they have not enjoyed the same level of popularity as in North America. For example, CBC circles have been established across Latin America but at lower densities than in North America, and most circles have been surveyed for a shorter period of time, i.e., $<30 \mathrm{yr}$ compared with $52 \mathrm{yr}$ in North America (National Audubon Society 2018). Similarly, eBird was launched in 2002 but did not reach Latin America immediately; the Central American portal launched in 2013, and the Brazilian portal in 2014 (eBird 2018). There are also fewer participants outside of North America. As of February 2018, there were $>23,500,000$ checklists from North America, > 383,000 checklists from Central America, and $>519,000$ checklists from South America (eBird 2018). A multisite capture-recapture program aimed at estimating demographic rates of migratory songbirds during the nonbreeding season has also been implemented (DeSante et al. 2005, Ruiz-Gutierrez et al. 2016); however, as for MAPS, species capture and recapture rates at individual sites are often low, and spatial and temporal coverage for many species remains poor. Increasing local participation in these citizen science programs could help alleviate the lack of long-term monitoring programs. Similarly, explanatory variables such as high-resolution land cover and climate data are also limited in Latin American wintering regions. Given the importance of nonbreeding regions for boreal bird populations, and the impact that nonbreeding processes can have on population trajectories, more observational data and covariates are urgently needed from regions beyond the boreal forest.

\section{A call for long-term collaborative projects}

Extending the spatial and temporal coverage of bird population monitoring schemes in the boreal forest will take decades of effort and a long-term commitment of resources. Long-term monitoring programs can take many decades before delivering reliable population trends (Gerrodette 1987, Hatch 2003), and the lack of commitment to maintaining long-term monitoring programs until they pay off has particularly hampered conservation efforts (Krebs 2015). Given the vagaries of time and changes in organizational priorities, monitoring programs that are built through collaborative efforts among government agencies, academia, and nongovernmental organizations are therefore more likely to survive. Through that lens, monitoring programs in the boreal forest will likely have their greatest chance of long-term success if they are broadly collaborative with initiatives such as the North American Bird Conservation Initiative and the North American Waterfowl Management Plan or integrative projects such as BAM, eBird, or the Avian Knowledge Network (AKN). The AKN, an international collaborative network dedicated to increasing data sharing and standardization, not only ensures long-term storage of avian data sets but also provides tools for accessing, exploring, and visualizing the data (Iliff et al. 2009). Collaboration between dedicated monitoring programs and these and other partners would have the advantage of leveraging additional data and increasing their capacity to address conservation issues, such as resource extraction and climate change, beyond the typical mandates of reporting species' status and trends. Ultimately, the broader use of monitoring data will increase the likelihood that conservation efforts can be actively informed not only within the boreal region itself but also in other areas used by boreal-breeding birds throughout their annual cycle.

\section{CONCLUSIONS}

Birds have long been recognized as exemplary environmental indicators. A strong multispecies monitoring program for migratory birds in the boreal forest could help track 
environmental changes attributable to anthropogenic perturbations and climatic changes in the boreal forest and develop conservation measures that would help us maintain resilient bird populations. We have many tools at our disposal to disentangle the signal from the noise and identify the main drivers of population trajectories and trends, but their use is limited by a lack of observational data and explanatory covariates. We can shore up the current lack of data via two pathways. First, we need more data on migratory birds. Although it will be possible to extend the coverage of some surveys, the remoteness of the boreal forest calls for the development of new omnibus, multispecies surveys that will enable us to expand survey coverage in the northern part of the boreal forest for the different groups of birds. Spatially balanced sampling designs with rotating panels could alleviate the cost of implementing these new surveys while also providing spatial and temporal coverage sufficient to detect significant population declines. Second, the best use of the data collected through monitoring would be achieved through the development of mechanistic population models for migratory birds. However, these models will require the appropriate spatiotemporal environmental covariates. Improving the accessibility of databases holding the explanatory variables will play a key role in our ability to develop a sound understanding of the population dynamics of migratory birds in the boreal forest. Given the magnitude and complexity of this challenge, it will be important to develop multidisciplinary working groups to coordinate the development of new monitoring strategies and the consolidation of monitoring data and explanatory covariates.

Responses to this article can be read online at: http://www.ace-eco.org/issues/responses.php/1397

\section{Acknowledgments:}

We thank S. Cumming, E. Elizondo, P. Flint, J. Grand, M. Kéry, S. Matsuoka, G. McNeil, T. Meehan, J. Pearce, O. Robinson, V. Ruiz, W. Thogmartin, C. Wilsey, S. Wilson, J. Wu, and an anonymous reviewer for useful discussions and feedback on the manuscript. We also thank the organizers of the Conservation of Boreal Birds Workshop at the 2016 North American Congress for Conservation Biology in Wisconsin for giving us the opportunity to present and discuss these thoughts. This work was supported in part by funding from the Wildlife Program of the U. S. Geological Survey's Ecosystem Mission Area. Any use of trade, firm, or product names is for descriptive purposes only and does not imply endorsement by the U.S. government.

\section{LITERATURE CITED}

Ahrestani, F. S., J. F. Saracco, J. R. Sauer, K. L. Pardieck, and J. A. Royle. 2017. An integrated population model for bird monitoring in North America. Ecological Applications 27:916-924. http://dx.doi.org/10.1002/eap.1493

Albert, S., D. DeSante, D. Kaschube, and J. F. Saracco. 2016. MAPS (Monitoring Avian Productivity and Survivorship) data provide inferences on demographic drivers of population trends for 158 species of North American landbirds. North American
Bird Bander 41:133-140. [online] URL: https://www.birdpop.org/ docs/pubs/Albert_et_al_2016_MAPS_Data_Provide_Inf_on_Demographic_Drivers.pdf

Alisauskas, R. T., K. L. Drake, and J. D. Nichols. 2009. Filling a void: abundance estimation of North American populations of Arctic geese using hunter recoveries. Pages 463-489 in D. L. Thompson, E. G. Cooch, and M. L. Conroy, editors. Modeling demographic processes in marked populations. Springer, Boston, Massachusetts, USA. http://dx.doi.org/10.1007/978-0-387-78151-8_20

Altwegg, R., A. Jenkins, and F. Abadi. 2014. Nestboxes and immigration drive the growth of an urban Peregrine Falcon Falco peregrinus population. Ibis 156:107-115. http://dx.doi.org/10.1111/ ibi. 12125

Amundson, C. L., J. A. Royle, and C. M. Handel. 2014. A hierarchical model combining distance sampling and time removal to estimate detection probability during avian point counts. Auk 131:476-494. http://dx.doi.org/10.1642/AUK-14-11.1

Anderson, S. C., T. A. Branch, A. B. Cooper, and N. K. Dulvy. 2017. Black-swan events in animal populations. Proceedings of the National Academy of Sciences of the United States of America 114:3252-3257. http://dx.doi.org/10.1073/pnas.1611525114

Andrewartha, H. G., and L. C. Birch. 1954. The distribution and abundance of animals. University of Chicago Press, Chicago, Illinois, USA.

Arnold, T. W. 2018. Using ring-recovery and within-season recapture data to estimate fecundity and population growth. Ecology and Evolution 8:10298- 10305. https://dx.doi. org/10.1002/ece3.4506

Banskota, A., N. Kayastha, M. J. Falkowski, M. A. Wulder, R. E. Froese, and J. C. White. 2014. Forest monitoring using Landsat time series data: a review. Canadian Journal of Remote Sensing 40:362-384. http://dx.doi.org/10.1080/07038992.2014.987376

Barker, N. K. S., P. C. Fontaine, S. G. Cumming, D. Stralberg, A. Westwood, E. M. Bayne, P. Sólymos, F. K. A. Schmiegelow, S. J. Song, and D. J. Rugg. 2015. Ecological monitoring through harmonizing existing data: lessons from the Boreal Avian Modelling Project. Wildlife Society Bulletin 39:480-487. http://dx. doi.org/10.1002/wsb.567

Barker, R. J., M. R. Schofield, W. A. Link, and J. R. Sauer. 2018. On the reliability of N-mixture models for count data. Biometrics 74:369-377. http://dx.doi.org/10.1111/biom.12734

Barker, N. K. S., S. M. Slattery, M. Darveau, and S. G. Cumming. 2014. Modeling distribution and abundance of multiple species: different pooling strategies produce similar results. Ecosphere 5:1-24. http://dx.doi.org/10.1890/ES14-00256.1

Barraquand, F., S. Louca, K. C. Abbott, C. A. Cobbold, F. Cordoleani, D. L. DeAngelis, B. D. Elderd, J. W. Fox, P. Greenwood, F. M. Hilker, D. L. Murray, C. R. Stieha, R. A. Taylor, K. Vitense, G. S. K. Wolkowicz, and R. C. Tyson. 2017. Moving forward in circles: challenges and opportunities in modelling population cycles. Ecology Letters 20:1074-1092. http://dx.doi.org/10.1111/ele.12789

Bart, J., B. Andres, S. Brown, G. Donaldson, B. A. Harrington, V. Johnston, S. Jones, R. I. G. Morrison, and S. Skagen. 2005. 
The Program for Regional and International Shorebird Monitoring (PRISM). Pages 896-901 in C. J. Ralph and T. D. Rich, editors. Bird conservation implementation and integration in the Americas: proceedings of the Third International Partners in Flight Conference (Asilomar, California, 20-24 March 2002). Volume 2. U.S. Forest Service General Technical Report No. PSWGTR-191. U.S. Forest Service, Pacific Southwest Research Station, Albany, California, USA.

Bart, J., and S. Earnst. 2002. Double sampling to estimate density and population trends in birds. Auk 119:36-45. https://dx.doi. org/10.2307/4090010

Bateman, B. L., A. M. Pidgeon, V. C. Radeloff, C. H. Flather, J. VanDerWal, H. R. Akçakaya, W. E. Thogmartin, T. P. Albright, S. J. Vavrus, and P. J. Heglund. 2016. Potential breeding distributions of U.S. birds predicted with both short-term variability and long-term average climate data. Ecological Applications 26:2720-2731. http://dx.doi.org/10.1002/eap.1416

Berryman, A. A. 2002. Population: a central concept for ecology? Oikos 97:439-442. https://dx.doi.org/10.1034/j.1600-0706.2002.970314. $\mathrm{x}$

Berthold, P. 2001. Bird migration: a general survey. Oxford University Press, Oxford, UK.

Besbeas, P., S. N. Freeman, B. J. T. Morgan, and E. A. Catchpole. 2002. Integrating mark-recapture-recovery and census data to estimate animal abundance and demographic parameters. Biometrics 58:540-547. https://dx.doi.org/10.1111/j.0006-341X.2002.00540. $\mathrm{x}$

Blancher, P. J., R. D. Phoenix, D. S. Badzinski, M. D. Cadman, T. L. Crewe, C. M. Downes, D. Fillman, C. M. Francis, J. Hughes, D. J. T. Hussell, D. Lepage, J. D. McCracken, D. K. McNicol, B. A. Pond, R. K. Ross, R. Russell, L. A. Venier, and R. C. Weeber. 2009. Population trend status of Ontario's forest birds. Forestry Chronicle 85:184-201. http://dx.doi.org/10.5558/tfc85184-2

Blohm, R. J., D. E. Sharp, P. I. Padding, and K. D. Richkus. 2006. Monitoring North America's waterfowl resource. Pages 448-452 in G. C. Boere, C. A. Galbraith, and D. A. Stroud, editors. Waterbirds around the world. The Stationery Office, Edinburgh, UK.

Bolker, B. M. 2008. Ecological models and data in R. Princeton University Press, Princeton, New Jersey, USA. https://doi. org/10.2307/j.ctvem4g37

Boyd W. S., T. D. Bowman, J. P. L. Savard, and R. D. Dickson. 2015. Conservation of North American sea ducks. Pages 529-559 in J. P. L. Savard, D. V. Derksen, D. Esler, and J. M. Eadie, editors. Ecology and conservation of North American sea ducks. CRC Press, Boca Raton, Florida, USA.

Brandt, J. P. 2009. The extent of the North American boreal zone. Environmental Reviews 17:101-161. https://dx.doi.org/10.1139/ A09-004

Brownie, C., D. R. Anderson, K. P. Burnham, and D. S. Robson. 1985. Statistical inference from band recovery data - a handbook. Resource Publication No. 156. U.S. Department of Interior, Fish and Wildlife Service, Washington, D.C., USA.
Buckland, S. T., D. R. Anderson, K. P. Burnham, J. L. Laake, D. L. Borchers, and L. Thomas. 2001. Introduction to distance sampling: estimating abundance of wildlife populations. Oxford University Press, New York, New York, USA.

Burton, C., D. Huggard, E. Bayne, J. Schieck, P. Sólymos, T. Muhly, D. Farr, and S. Boutin. 2014. A framework for adaptive monitoring of the cumulative effects of human footprint on biodiversity. Environmental Monitoring and Assessment 186:3605-3617. https://dx.doi.org/10.1007/s10661-014-3643-7

Butchart, S. H. M., A. J. Stattersfield, L. A. Bennun, S. M. Shutes, H. R. Akçakaya, J. E. M. Baillie, S. N. Stuart, C. Hilton-Taylor, and G. M. Mace. 2004. Measuring global trends in the status of biodiversity: Red List indices for birds. PLoS Biology 2(12):e383. http://dx.doi.org/10.1371/journal.pbio.0020383

Calvert, A. M., C. A. Bishop, R. D. Elliot, E. A. Krebs, T. M. Kydd, C. S. Machtans, and G. J. Robertson. 2013. A synthesis of human-related avian mortality in Canada. Avian Conservation and Ecology 8(2):11. http://dx.doi.org/10.5751/ace-00581-080211

Camus, P. A., and F. De Ciencias. 2002. Populations, metapopulations, and the open-closed dilemma: the conflict between operational and natural population concepts. Oikos 97:433-438. http://dx.doi.org/10.1034/j.1600-0706.2002.970313. $\mathrm{x}$

Chandler, R. B., and J. D. Clark. 2014. Spatially explicit integrated population models. Methods in Ecology and Evolution 5:1351-1360. http://dx.doi.org/10.1111/2041-210x.12153

Clark, J. S., and O. N. Bjørnstad. 2004. Population time series: process variability, observation errors, missing values, lags, and hidden states. Ecology 85:3140-3150. http://dx.doi.org/10.1890/03-0520

Clark, F., B. W. Brook, S. Delean, H. R. Akçakaya, and C. J. A. Bradshaw. 2010. The theta-logistic is unreliable for modelling most census data. Methods in Ecology and Evolution 1:253-262. http://dx.doi.org/10.1111/j.2041-210x.2010.00029.x

Clark, J. S., G. Ferraz, N. Oguge, H. Hays, and J. DiCostanzo. 2005. Hierarchical Bayes for structured, variable populations: from recapture data to life-history prediction. Ecology 86:2232-2244. http://dx.doi.org/10.1890/04-1348

Cohen, E. B., J. A. Hostetler, M. T. Hallworth, C. S. Rushing, T. S. Sillett, and P. P. Marra. 2018. Quantifying the strength of migratory connectivity. Methods in Ecology and Evolution 9:513-524. https://dx.doi.org/10.1111/2041-210X.12916

Connors, B. M., A. B. Cooper, R. M. Peterman, and N. K. Dulvy. 2014. The false classification of extinction risk in noisy environments. Proceedings of the Royal Society B: Biological Sciences 281:20132935. http://dx.doi.org/10.1098/rspb.2013.2935

Cooke, H. A., and S. J. Hannon. 2012. Nest-site selection by old boreal forest cavity excavators as a basis for structural retention guidelines in spatially-aggregated harvests. Forest Ecology and Management 269:37-51. http://dx.doi.org/10.1016/j.foreco.2011.12.042

Cosco, J. A. 2011. Common attribute schema (CAS) for forest inventories across Canada. Boreal Avian Modelling Project; Canadian BEACONs Project, Edmonton, Alberta, Canada. [online] URL: https://zenodo.org/record/2433719\#.XUC75HF7mUk 
Cox, W. A., F. R. Thompson, III, J. L. Reidy, and J. Faaborg. 2013. Temperature can interact with landscape factors to affect songbird productivity. Global Change Biology 19:1064-1074. http://dx.doi.org/10.1111/gcb.12117

Cumming, S. G., C. R. Drever, M. Houle, J. Cosco, P. Racine, E. Bayne, and F. K. A. Schmiegelow. 2015. A gap analysis of tree species representation in the protected areas of the Canadian boreal forest: applying a new assemblage of digital Forest Resource Inventory data. Canadian Journal of Forest Research 45:163-173. https://dx.doi.org/10.1139/cjfr-2014-0102

Cumming, S. G., K. L. Lefevre, E. Bayne, T. Fontaine, F. K. A. Schmiegelow, and S. J. Song. 2010. Toward conservation of Canada's boreal forest avifauna: design and application of ecological models at continental extents. Avian Conservation and Ecology 5(2):8. http://dx.doi.org/10.5751/ace-00406-050208

Cyr, D., S. Gauthier, Y. Bergeron, and C. Carcaillet. 2009. Forest management is driving the eastern North American boreal forest outside its natural range of variability. Frontiers in Ecology and the Environment 7:519-524. http://dx.doi.org/10.1890/080088

Dail, D., and L. Madsen. 2011. Models for estimating abundance from repeated counts of an open metapopulation. Biometrics 67:577-587. http://dx.doi.org/10.1111/j.1541-0420.2010.01465.x

Deluca, W. V., and D. I. King. 2014. Influence of hiking trails on montane birds. Journal of Wildlife Management 78:494-502. http://dx.doi.org/10.1002/jwmg.675

Dennis, B., J. M. Ponciano, S. R. Lele, M. L. Taper, and D. F. Staples. 2006. Estimating density dependence, process noise, and observation error. Ecological Monographs 76:323-341. http://dx. doi.org/10.1890/0012-9615(2006)76[323:eddpna]2.0.co;2

d'Eon-Eggertson, F., N. K. Dulvy, and R. M. Peterman. 2015. Reliable identification of declining populations in an uncertain world. Conservation Letters 8:86-96. http://dx.doi.org/10.1111/ conl.12123

DeSante, D. F., D. R. Kaschube, and J. F. Saracco. 2015. Vital rates of North American landbirds. The Institute for Bird Populations, Point Reyes Station, California, USA. [online] URL: www.VitalRatesOfNorthAmericanLandbirds.org

DeSante, D. F., D. R. O'Grady, and P. Pyle. 1999. Measures of productivity and survival derived from standardized mist-netting are consistent with observed population changes. Bird Study 46 (S1):S178-S188. http://dx.doi.org/10.1080/00063659909477244

DeSante, D. F., T. S. Sillett, R. B. Siegel, J. F. Saracco, C. A. Romo de Vivar Alvarez, S. Morales, A. Cerezo, D. Kaschube, B. Milá, and M. Grosselet. 2005. MoSI (Monitoreo de Sobrevivencia Invernal): assessing habitat-specific overwintering survival of neotropical migratory landbirds. Pages 926-936 in C. J. Ralph and T. D. Rich, editors. Bird conservation implementation and integration in the Americas: proceedings of the Third International Partners in Flight Conference (Asilomar, California, 20-24 March 2002). Volume 2. U.S. Forest Service General Technical Report No. PSW-GTR-191. U.S. Forest Service, Pacific Southwest Research Station, Albany, California, USA.

Dionne, M., C. Maurice, J. Gauthier, and F. Shaffer. 2008. Impact of Hurricane Wilma on migrating birds: the case of the Chimney
Swift. Wilson Journal of Ornithology 120:784-792. https://dx.doi. org/10.1676/07-123.1

Dormann, C. F., J. M. MacPherson, M. B. Araújo, R. Bivand, J. Bolliger, G. Carl, R. G. Davies, A. Hirzel, W. Jetz, D. Kissling, I. Kühn, R. Ohlemüller, P. R. Peres-Neto, B. Reineking, B. Schröder, F. M. Schurr, and R. Wilson. 2007. Methods to account for spatial autocorrelation in the analysis of species distributional data: a review. Ecography 30:609-628. http://dx.doi.org/10.1111/ j.2007.0906-7590.05171.x

Drever, C. R., G. Peterson, C. Messier, Y. Bergeron, and M. Flannigan. 2006. Can forest management based on natural disturbances maintain ecological resilience? Canadian Journal of Forest Research 36:2285-2299. http://dx.doi.org/10.1139/x06-132

Drever, M. C., A. C. Smith, L. A. Venier, D. J. H. Sleep, and D. A. MacLean. 2018. Cross-scale effects of spruce budworm outbreaks on boreal warblers in eastern Canada. Ecology and Evolution 8:7334-7345. https://dx.doi.org/10.1002/ece3.4244

Droege, S. 1990. The North American Breeding Bird Survey. Pages 1-4 in J. R. Sauer and S. Droege, editors. Survey designs and statistical methods for the estimation of avian population trends. Biological Report 90(1). U.S. Fish and Wildlife Service, Washington, D.C., USA.

Duarte, A., F. W. Weckerly, M. Schaub, and J. S. Hatfield. 2016. Estimating golden-cheeked Warbler immigration: implications for the spatial scale of conservation. Animal Conservation 19:65-74. http://dx.doi.org/10.1111/acv.12217

Dunn, E. H. 2002. Using decline in bird populations to identify needs for conservation action. Conservation Biology 16:1632-1637. http://dx.doi.org/10.1046/j.1523-1739.2002.01250.x

Dunn, E. H., B. L. Altman, J. Bart, C. J. Beardmore, H. Berlanga, P. J. Blancher, G. S. Butcher, D. W. Demarest, R. Dettmers, W. C. Hunter, E. E. Iñigo-Elias, A. O. Panjabi, D. N. Pashley, C. J. Ralph, T. D. Rich, K. V. Rosenberg, C. M. Rustay, J. M. Ruth, and T. C. Will. 2005. High priority needs for range-wide monitoring of North American landbirds. Partners in Flight Technical Series No. 2. Partners in Flight, Laurel, Maryland, USA. [online] URL: https:// www.Partnersinflight.Org/wp-content/uploads/2017/03/PIF-TechnicalSeries-02-Monitoring-Needs.pdf

eBird. 2018. eBird: an online database of bird distribution and abundance [web application]. Cornell Lab of Ornithology, Ithaca, New York, USA. [online] URL: http://www.ebird.org

Farmer, R. G., M. L. Leonard, J. E. Mills Flemming, and S. C. Anderson. 2014. Observer aging and long-term avian survey data quality. Ecology and Evolution 4:2563-2576. https://dx.doi. org/10.1002/ece3.1101

Farnsworth, G. L., J. D. Nichols, J. R. Sauer, S. G. Fancy, K. H. Pollock, S. A. Shriner, and T. R. Simons. 2005. Statistical approaches to the analysis of point count data: a little extra information can go a long way. Pages 735-743 in C. J. Ralph and T. D. Rich, editors. Bird conservation implementation and integration in the Americas: proceedings of the Third International Partners in Flight Conference (Asilomar, California, 20-24 March 2002). Volume 2. U.S. Forest Service General Technical Report No. PSW-GTR-191. U.S. Forest Service, Pacific Southwest Research Station, Albany, California, USA. 
Farnsworth, G. L., K. H. Pollock, J. D. Nichols, T. R. Simons, J. E. Hines, and J. R. Sauer. 2002. A removal model for estimating detection probabilities from point-count surveys. Auk 119:414-425. http://dx.doi.org/10.1642/0004-8038(2002)119[0414: armfed]2.0.co;2

Fewster, R. M., S. T. Buckland, G. M. Siriwardena, S. R. Baillie, and J. D. Wilson. 2000. Analysis of population trends for farmland birds using generalized additive models. Ecology 81:1970-1984. http://dx.doi.org/10.2307/177286

Finley, A. O. 2011. Comparing spatially-varying coefficients models for analysis of ecological data with non-stationary and anisotropic residual dependence. Methods in Ecology and Evolution 2:143-154. http://dx.doi.org/10.1111/j.2041-210x.2010.00060. $\mathrm{x}$

Flesch, A. D., and R. J. Steidl. 2010. Importance of environmental and spatial gradients on patterns and consequences of resource selection. Ecological Applications 20:1021-1039. http://dx.doi. org/10.1890/09-0076.1

Fletcher, R. J., Jr., T. J. Hefley, E. P. Robertson, B. Zuckerberg, R. A. McCleery, and R. M. Dorazio. 2019. A practical guide for combining data to model species distributions. Ecology 100: e02710. http://dx.doi.org/10.1002/ecy.2710

Foster, S. D., G. R. Hosack, E. Lawrence, R. Przeslawski, P. Hedge, M. J. Caley, N. S. Barrett, A. Williams, J. Li, T. Lynch, J. M. Dambacher, H. P. A. Sweatman, and K. R. Hayes. 2017. Spatially balanced designs that incorporate legacy sites. Methods in Ecology and Evolution 8:1433-1442. http://dx.doi. org/10.1111/2041-210x.12782

Freckleton, R. P., A. R. Watkinson, R. E. Green, and W. J. Sutherland. 2006. Census error and the detection of density dependence. Journal of Animal Ecology 75:837-851. http://dx.doi. org/10.1111/j.1365-2656.2006.01121.x

Gerrodette, T. 1987. A power analysis for detecting trends. Ecology 68:1364-1372. http://dx.doi.org/10.2307/1939220

Grafström, A., N. L. P. Lundström, and L. Schelin. 2012. Spatially balanced sampling through the pivotal method. Biometrics 68:514-520. http://dx.doi.org/10.1111/j.1541-0420.2011.01699.x

Greenberg, R., D. W. Demarest, S. M. Matsuoka, C. MettkeHofmann, D. Evers, P. B. Hamel, J. Luscier, L. L. Powell, D. Shaw, M. L. Avery, K. A. Hobson, P. J. Blancher, and D. K. Niven. 2011. Understanding declines in Rusty Blackbirds. Pages 107-126 in J. V. Wells, editor. Boreal birds of North America: a hemispheric view of their conservation links and significance. Studies in Avian Biology 41. University of California Press, Berkeley, California, USA.

Gregoire, T. G. 1998. Design-based and model-based inference in survey sampling: appreciating the difference. Canadian Journal of Forest Research 28:1429-1447. http://dx.doi.org/10.1139/x98-166

Guindon, L., P. Bernier, S. Gauthier, G. Stinson, P. Villemaire, and A. Beaudoin. 2018. Missing forest cover gains in boreal forests explained. Ecosphere 9(1):e02094. http://dx.doi.org/10.1002/ ecs 2.2094

Hallworth, M. T., T. S. Sillett, S. L. Van Wilgenburg, K. A. Hobson, and P. P. Marra. 2015. Migratory connectivity of a
Neotropical migratory songbird revealed by archival light-level geolocators. Ecological Applications 25:336-347. http://dx.doi. org/10.1890/14-0195.1

Handel, C. M., and J. R. Sauer. 2017. Combined analysis of roadside and off-road breeding bird survey data to assess population change in Alaska. Condor 119:557-575. http://dx.doi. org/10.1650/condor-17-67.1

Hannon, S. J., and P. Drapeau. 2005. Bird responses to burns and clear cuts in the boreal forest of Canada. Pages 1104-1106 in C. J. Ralph and T. D. Rich, editors. Bird conservation implementation and integration in the Americas: proceedings of the Third International Partners in Flight Conference (Asilomar, California, 20-24 March 2002). Volume 2. U.S. Forest Service General Technical Report No. PSW-GTR-191. U.S. Forest Service, Pacific Southwest Research Station, Albany, California, USA.

Hansen, B. B., V. Grøtan, R. Aanes, B.-E. Sæther, A. Stien, E. Fuglei, R. A. Ims, N. G. Yoccoz, and A. Ø. Pedersen. 2013. Climate events synchronize the dynamics of a resident vertebrate community in the High Arctic. Science 339:313-315. http://dx. doi.org/10.1126/science. 1226766

Hanski, I. 1999. Metapopulation ecology. Oxford University Press, New York, New York, USA.

Hapfelmeier, A., T. Hothorn, K. Ulm, and C. Strobl. 2014. A new variable importance measure for random forests with missing data. Statistics and Computing 24:21-34. http://dx.doi. org/10.1007/s11222-012-9349-1

Hatch, S. A. 2003. Statistical power for detecting trends with applications to seabird monitoring. Biological Conservation 111:317-329. http://dx.doi.org/10.1016/s0006-3207(02)00301-4

Hefley, T. J., M. B. Hooten, J. M. Drake, R. E. Russell, and D. P. Walsh. 2016. When can the cause of a population decline be determined? Ecology Letters 19:1353-1362. http://dx.doi. org/10.1111/ele.12671

Hobson, K. A., K. J. Kardynal, S. L. Van Wilgenburg, G. Albrecht, A. Salvadori, M. D. Cadman, F. Liechti, and J. W. Fox. 2015. A continent-wide migratory divide in North American breeding Barn Swallows (Hirundo rustica). PLoS ONE 10(6): e0129340. http://dx.doi.org/10.1371/journal.pone.0129340

Hodgson, J. C., S. M. Baylis, R. Mott, A. Herrod, and R. H. Clarke. 2016. Precision wildlife monitoring using unmanned aerial vehicles. Scientific Reports 6:22574. http://dx.doi. org/10.1038/srep22574

Holopainen, S., C. Arzel, L. Dessborn, J. Elmberg, G. Gunnarsson, P. Nummi, H. Pöysä, and K. Sjöberg. 2015. Habitat use in ducks breeding in boreal freshwater wetlands: a review. European Journal of Wildlife Research 61:339-363. http://dx.doi. org/10.1007/s10344-015-0921-9

Howe, M. A., P. H. Geissler, and B. A. Harrington. 1989. Population trends of North American shorebirds based on the International Shorebird Survey. Biological Conservation 49:185-199. https://dx.doi.org/10.1016/0006-3207(89)90035-9

Hudson, M.-A. R., C. M. Francis, K. J. Campbell, C. M. Downes, A. C. Smith, and K. L. Pardieck. 2017. The role of the North American Breeding Bird Survey in conservation. Condor 119:526-545. http://dx.doi.org/10.1650/condor-17-62.1 
Iknayan, K. J., M. W. Tingley, B. J. Furnas, and S. R. Beissinger. 2014. Detecting diversity: emerging methods to estimate species diversity. Trends in Ecology and Evolution 29:97-106. http://dx. doi.org/10.1016/j.tree.2013.10.012

Iliff, M., L. Salas, E. R. Inzunza, G. Ballard, D. Lepage, and S. Kelling. 2009. The Avian Knowledge Network: a partnership to organize, analyze, and visualize bird observation data for education, conservation, research, and land management. Pages 365-373 in T. D. Rich, C. Arizmendi, D. W. Demarest, and C. Thompson, editors. Tundra to tropics: proceedings of the Fourth International Partners in Flight Conference (McAllen, Texas, 13-16 February 2008). U.S. Forest Service, Pacific Southwest Research Station, Albany, California, USA. [online] URL: https://www.fs. fed.us/psw/publications/4251/psw_2009_salas(iliff)001.pdf

Innovation, Science and Economic Development Canada. 2016. Tri-agency open access policy on publications. Government of Canada, Ottawa, Ontario, Canada. [online] URL: http://www. science.gc.ca/eic/site/063.nsf/eng/h_F6765465.html

Ioannidis, J. P. A. 2005. Why most published research findings are false. PLoS Medicine 2(8):e124. http://dx.doi.org/10.1371/ journal.pmed.0020124

Johnson, L. R., T. Ben-Horin, K. D. Lafferty, A. McNally, E. Mordecai, K. P. Paaijmans, S. Pawar, and S. J. Ryan. 2015. Understanding uncertainty in temperature effects on vectorborne disease: a Bayesian approach. Ecology 96:203-213. http:// dx.doi.org/10.1890/13-1964.1

Johnson, D. H., and J. W. Grier. 1988. Determinants of breeding distributions of ducks. Wildlife Monographs 100:1-37.

Johnston, A., D. Fink, W. M. Hochachka, and S. Kelling. 2018. Estimates of observer expertise improve species distributions from citizen science data. Methods in Ecology and Evolution 9:88-97. http://dx.doi.org/10.1111/2041-210X.12838

Kardynal, K. J., K. A. Hobson, S. L. Van Wilgenburg, and J. L. Morissette. 2009. Moving riparian management guidelines towards a natural disturbance model: an example using boreal riparian bird communities. Forest Ecology and Management 257:54-65. http://dx.doi.org/10.1016/j.foreco.2008.08.029

Keith, D., H. R. Akçakaya, S. H. M. Butchart, B. Collen, N. K. Dulvy, E. E. Holmes, J. A. Hutchings, D. Keinath, M. K. Schwartz, A. O. Shelton, and R. S. Waples. 2015. Temporal correlations in population trends: conservation implications from time-series analysis of diverse animal taxa. Biological Conservation 192:247-257. http://dx.doi.org/10.1016/j.biocon.2015.09.021

Kendall, W. L., B. G. Peterjohn, and J. R. Sauer. 1996. First-time observer effects in the North American Breeding Bird Survey. Auk 113:823-829. http://dx.doi.org/10.2307/4088860

Kéry, M. 2018. Identifiability in $N$-mixture models: a large-scale screening test with bird data. Ecology 99:281-288. http://dx.doi. org/10.1002/ecy.2093

Kéry, M., and J. A. Royle. 2016. Applied hierarchical modeling in ecology: analysis of distribution, abundance and species richness in $R$ and BUGS. Volume 1, prelude and static models. Academic Press, London, UK. https://doi.org/10.1016/C2013-0-19160-X
Kéry, M., and M. Schaub. 2012. Bayesian population analysis using WinBUGS: a hierarchical perspective. Academic Press, New York, New York, USA.

Kirk, D. A. and C. Hyslop. 1998. Population status and recent trends in Canadian raptors: a review. Biological Conservation 83:91-118.https://doi.org/10.1016/S0006-3207(97)00051-7

Knape, J. 2008. Estimability of density dependence in models of time series data. Ecology 89:2994-3000. http://dx.doi. org/10.1890/08-0071.1

Knape, J. 2016. Decomposing trends in Swedish bird populations using generalized additive mixed models. Journal of Applied Ecology 53:1852-1861. http://dx.doi.org/10.1111/1365-2664.12720

Knape, J., and P. de Valpine. 2012. Are patterns of density dependence in the Global Population Dynamics Database driven by uncertainty about population abundance? Ecology Letters 15:17-23. http://dx.doi.org/10.1111/j.1461-0248.2011.01702.x

Koenig, W. D., and J. M. H. Knops. 2001. Seed-crop size and eruptions of North American boreal seed-eating birds. Journal of Animal Ecology 70:609-620. http://dx.doi.org/10.1046/ j.1365-2656.2001.00516.X

Koenig, W. D., and A. M. Liebhold. 2016. Temporally increasing spatial synchrony of North American temperature and bird populations. Nature Climate Change 6:614-617. http://dx.doi. org/10.1038/nclimate2933

Koons, D. N., T. W. Arnold, and M. Schaub. 2017. Understanding the demographic drivers of realized population growth rates. Ecological Applications 27:2102-2115. http://dx.doi.org/10.1002/ eap. 1594

Krebs, C. J. 2015. One hundred years of population ecology: successes, failures and the road ahead. Integrative Zoology 10:233-240. http://dx.doi.org/10.1111/1749-4877.12130

Lamanna, J. A., T. L. George, J. F. Saracco, M. P. Nott, and D. F. DeSante. 2012. El Niño-Southern Oscillation influences annual survival of a migratory songbird at a regional scale. Auk: Ornithological Advances 129:734-743. https://dx.doi.org/10.1525/ auk.2012.12017

Lancia, R. A., W. L. Kendall, K. H. Pollock, and J. D. Nichols. 2005. Estimating the number of animals in wildlife populations. Pages 106-153 in E. B. Clait, editor. Techniques for wildlife investigations and management. Wildlife Society, Bethesda, Maryland, USA.

Lande, R., S. Engen, and B.-E. Sæther. 2003. Stochastic population dynamics in ecology and conservation. Oxford University Press, Oxford, UK. https://doi.org/10.1093/acprof:oso/9780198525257.001.0001

Langham, G. M., J. G. Schuetz, T. Distler, C. U. Soykan, and C. Wilsey. 2015. Conservation status of North American Birds in the face of future climate change. PLoS ONE 10(9):e0135350. http://dx.doi.org/10.1371/journal.pone.0135350

LaSorte, F. A., C. A. Lepczyk, J. L. Burnett, A. H. Hurlbert, M. W. Tingley, and B. Zuckerberg. 2018. Opportunities and challenges for big data ornithology. Condor 120:414-426. http:// dx.doi.org/10.1650/CONDOR-17-206.1 
Lawler, J. J., and R. J. O'Connor. 2004. How well do consistently monitored breeding bird survey routes represent the environments of the conterminous United States? Condor 106:801-814. http://dx.doi.org/10.1650/7472

Lebreton, J.-D., K. P. Burnham, J. Clobert, and D. R. Anderson. 1992. Modeling survival and testing biological hypotheses using marked animals: a unified approach with case studies. Ecological Monographs 62:67-118. http://dx.doi.org/10.2307/2937171

Lebreton, J.-D., and O. Gimenez. 2013. Detecting and estimating density dependence in wildlife populations. Journal of Wildlife Management 77:12-23. http://dx.doi.org/10.1002/jwmg.425

Legg, C. J., and L. Nagy. 2006. Why most conservation monitoring is, but need not be, a waste of time. Journal of Environmental Management 78:194-199. http://dx.doi.org/10.1016/j.jenvman.2005.04.016

Lewis, T. L., J. A. Schmutz, C. L. Amundson, and M. S. Lindberg. 2016. Waterfowl populations are resilient to immediate and lagged impacts of wildfires in the boreal forest. Journal of Applied Ecology 53:1746-1754. http://dx.doi.org/10.1111/1365-2664.12705

Lincoln, F. C. 1930. Calculating waterfowl abundance on the basis of banding returns. U.S. Department of Agriculture Circular No. 118. U.S. Department of Agriculture, Washington, D.C., USA.

Lindberg, M. S. 2012. A review of designs for capture-markrecapture studies in discrete time. Journal of Ornithology 152 (S2):355-370. http://dx.doi.org/10.1007/s10336-010-0533-9

Lindenmayer, D. B. and G.E. Likens. 2009. Adaptive monitoring: a new paradigm for long-term research and monitoring. Trends in Ecology and Evolution 24:482-486. http://dx.doi.org/10.1016/j. tree.2009.03.005

Lindenmayer, D. B., G. E. Likens, A. Andersen, D. Bowman, C. M. Bull, E. Burns, C. R. Dickman, A. A. Hoffmann, D. A. Keith, M. J. Liddell, A. J. Lowe, D. J. Metcalfe, S. R. Phinn, J. RussellSmith, N. Thurgate, and G. M. Wardle. 2012. Value of long-term ecological studies. Austral Ecology 37:745-757. https://doi. org/10.1111/j.1442-9993.2011.02351.X

Link, W. A., M. R. Schofield, R. J. Barker, and J. R. Sauer. 2018. On the robustness of N-mixture models. Ecology 99:1547-1551. http://dx.doi.org/10.1002/ecy.2362

Loarie, S. R., P. B. Duffy, H. Hamilton, G. P. Asner, C. B. Field, and D. D. Ackerly. 2009. The velocity of climate change. Nature 462:1052-1055. http://dx.doi.org/10.1038/nature08649

Ludwig, G. 2007. Mechanisms of population declines in boreal forest grouse. Dissertation. University of Jyväskylä, Jyväskylä, Finland.

Luoto, M., R. Virkkala, and R. K. Heikkinen. 2007. The role of land cover in bioclimatic models depends on spatial resolution. Global Ecology and Biogeography 16:34-42. http://dx.doi. org/10.1111/j.1466-8238.2006.00262.X

Lyons, J. E., M. C. Runge, H. P. Laskowski, and W. L. Kendall. 2008. Monitoring in the context of structured decision-making and adaptive management. Journal of Wildlife Management 72:1683-1692. https://dx.doi.org/10.2193/2008-141

Machtans, C. S., K. J. Kardynal, and P. A. Smith. 2014. How well do regional or national Breeding Bird Survey data predict songbird population trends at an intact boreal site? Avian Conservation and Ecology 9(1):5. http://dx.doi.org/10.5751/ ace-00649-090105

Machtans, C. S., S. L. Van Wilgenburg, L. A. Armer, and K. A. Hobson. 2007. Retrospective comparison of the occurrence and abundance of Rusty Blackbird in the Mackenzie Valley, Northwest Territories. Avian Conservation and Ecology 2(1):3. http://dx.doi.org/10.5751/ace-00106-020103

Macias Fauria, M., and E. A. Johnson. 2008. Climate and wildfires in the North American boreal forest. Philosophical Transactions of the Royal Society B: Biological Sciences 363:2315-2327. http://dx.doi.org/10.1098/rstb.2007.2202

MacKenzie, D. I. 2005. What are the issues with presence-absence data for wildlife managers? Journal of Wildlife Management 69:849-860. http://dx.doi.org/10.2193/0022-541x(2005)069[0849: watiwp]2.0.co;2

Mahon, C. L., G. L. Holloway, E. M. Bayne, and J. D. Toms. 2019. Additive and interactive cumulative effects on boreal landbirds: winners and losers in a multi-stressor landscape. Ecological Applications 29(5):e01895.

Mallory, M. L., L. A. Venier, and D. McKenney. 2003. Winter weather and waterfowl surveys in north-western Ontario, Canada. Journal of Biogeography 30:441-448. http://dx.doi. org/10.1046/j.1365-2699.2003.00819.x

Matsuoka, S. M., C. L. Mahon, C. M. Handel, P. Sólymos, E. M. Bayne, P. C. Fontaine, and C. J. Ralph. 2014. Reviving common standards in point-count surveys for broad inference across studies. Condor 116:599-608. http://dx.doi.org/10.1650/condor-14-108.1

Matsuoka, S., P. Sólymos, T. Fontaine, and E. M. Bayne. 2011. Roadside surveys of boreal forest birds: how representative are they and how can we improve current sampling? Report to Environment Canada, Canadian Wildlife Service. University of Alberta, Edmonton, Alberta, Canada. [online] URL: https://zenodo.org/ record/1435868\#.XUC8V3F7mUk

McClure, C. J. W., N. D. Burkett-Cadena, R. A. Ligon, and G. E. Hill. 2011. Actual or perceived abundance? Interpreting annual survey data in the face of changing phenologies. Condor 113:490-500. https://dx.doi.org/10.1525/cond.2011.100234

McClure, C. J. W., B. W. Rolek, K. McDonald, and G. E. Hill. 2012. Climate change and the decline of a once common bird. Ecology and Evolution 2:370-378. http://dx.doi.org/10.1002/ ece 3.95

McKinnon, E. A., C. Q. Stanley, and B. J. M. Stutchbury. 2015. Carry-over effects of nonbreeding habitat on start-to-finish spring migration performance of a songbird. PLOS ONE 10(11): e0141580. http://dx.doi.org/10.1371/journal.pone.0141580

Mennill, D. J., M. Battiston, D. R. Wilson, J. R. Foote, and S. M. Doucet. 2012. Field test of an affordable, portable, wireless microphone array for spatial monitoring of animal ecology and behaviour. Methods in Ecology and Evolution 3:704-712. http:// dx.doi.org/10.1111/j.2041-210x.2012.00209.x

Michel, N. L., A. C. Smith, R. G. Clark, C. A. Morrissey, and K. A. Hobson. 2016. Differences in spatial synchrony and interspecific concordance inform guild-level population trends 
for aerial insectivorous birds. Ecography 39:774-786. http://dx. doi.org/10.1111/ecog.01798

Miller, D. A. W., K. Pacifici, J. S. Sanderlin, and B. J. Reich. 2019. The recent past and promising future for data integration methods to estimate species' distributions. Methods in Ecology and Evolution 10:22-37. http://dx.doi.org/10.1111/2041-210X.13110

Moreno, J., and A. P. Møller. 2011. Extreme climatic events in relation to global change and their impact on life histories. Current Zoology 57:375-389. http://dx.doi.org/10.1093/czoolo/57.3.375

Morissette, J. L., T. P. Cobb, R. M. Brigham, and P. C. James. 2002. The response of boreal forest songbird communities to fire and post-fire harvesting. Canadian Journal of Forest Research 32:2169-2183. http://dx.doi.org/10.1139/x02-134

Nakagawa, S. 2015. Missing data: mechanisms, methods and messages. Pages 81-105 in G. Fox, S. Negrete-Yankelevich, and J. V. Sosa, editors. Ecological statistics: contemporary theory and application. Oxford University Press, Oxford, UK.

National Audubon Society. 2018. The Christmas Bird Count historical results. National Audubon Society, New York, New York, USA. [online] URL: http://netapp.audubon.org/cbcobservation/

National Science Foundation [NSF]. 2015. Public access to results of NSF-funded research. NSF, Alexandria, Virginia, USA. [online] URL: http://www.nsf.gov/news/special_reports/public_access/

Naugle, D. E., R. R. Johnson, T. R. Cooper, M. M. Holland, and K. F. Higgins. 2000. Temporal distribution of waterfowl in eastern South Dakota: implications for aerial surveys. Wetlands 20:177-183. https://dx.doi.org/10.1672/0277-5212(2000)020[0177: TDOWIE]2.0.CO;2

Nichols, J. D., and J. E. Hines. 2002. Approaches for the direct estimation of $\lambda$, and demographic contributions to $\lambda$, using capture-recapture data. Journal of Applied Statistics 29 (1-4):539-568. http://dx.doi.org/10.1080/02664760120108809

Nichols, J. D., J. E. Hines, J.-D., Lebreton, and R. Pradel, $2000 a$. Estimation of contributions to population growth: a reverse-time capture-recapture approach. Ecology 81:3362-3376. https://doi. org/10.1890/0012-9658(2000)081[3362:EOCTPG]2.0.CO;2

Nichols, J. D., J. E. Hines, J. R. Sauer, F. W. Fallon, J. E. Fallon, and P. J. Heglund. 2000b. A double-observer approach for estimating detection probability and abundance from point counts. Auk 117:393-408. http://dx.doi.org/10.2307/4089721

Nichols, J. D., L. Thomas, and P. B. Conn. 2009. Inferences about landbird abundance from count data: recent advances and future directions. Pages 201-235 in D. L. Thomson, E. G. Cooch, and M. J. Conroy, editors. Modeling demographic processes in marked populations. Springer, Boston, Massachusetts, USA. https://doi. org/10.1007/978-0-387-78151-8_9

Nichols, J. D., and B. K. Williams. 2006. Monitoring for conservation. Trends in Ecology and Evolution 21:668-673. http:// dx.doi.org/10.1016/j.tree.2006.08.007

Niemi, G., J. Hanowski, P. Helle, R. Howe, M. Mönkkönen, L. Venier, and D. Welsh. 1998. Ecological sustainability of birds in boreal forests. Conservation Ecology 2(2):17. https://doi. org/10.5751/ES-00079-020217
North American Bird Conservation Initiative. 2016. The state of North America's birds 2016. Environment and Climate Change Canada, Ottawa, Ontario, Canada. [online] URL: http://www. StateoftheBirds.org

Nott, M. P., D. F. DeSante, R. B. Siegel, and P. Pyle. 2002. Influences of the El Niño/Southern Oscillation and the North Atlantic Oscillation on avian productivity in forests of the Pacific Northwest of North America. Global Ecology and Biogeography 11:333-342. https://doi.org/10.1046/j.1466-822X.2002.00296.x

Oedekoven, C. S., S. T. Buckland, M. L. Mackenzie, R. King, K. O. Evans, and L. W. Burger, Jr. 2014. Bayesian methods for hierarchical distance sampling models. Journal of Agricultural, Biological, and Environmental Statistics 19:219-239. http://dx.doi. org/10.1007/s13253-014-0167-0

Oliver, T. H., and M. D. Morecroft. 2014. Interactions between climate change and land use change on biodiversity: attribution problems, risks, and opportunities. Wiley Interdisciplinary Reviews: Climate Change 5:317-335. http://dx.doi.org/10.1002/ wcc. 271

Oppel, S., G. Hilton, N. Ratcliffe, C. Fenton, J. Daley, G. Gray, J. Vickery, and D. Gibbons. 2014. Assessing population viability while accounting for demographic and environmental uncertainty. Ecology 95:1809-1818. http://dx.doi.org/10.1890/13-0733.1

Pacifici, K., B. J. Reich, D. A. W. Miller, B. Gardner, G. Stauffer, S. Singh, A. McKerrow, and J. A. Collazo. 2017. Integrating multiple data sources in species distribution modeling: a framework for data fusion. Ecology 98:840-850. http://dx.doi. org/10.1002/ecy. 1710

Pacifici, K., T. R. Simons, and K. H. Pollock. 2008. Effects of vegetation and background noise on the detection process in auditory avian point-count surveys. Auk 125:600-607. http://dx. doi.org/10.1525/auk.2008.07078

Pankratz, R. F., S. Hache, P. Sólymos, and E. M. Bayne. 2017. Potential benefits of augmenting road-based breeding bird surveys with autonomous recordings. Avian Conservation and Ecology 12(2):18. http://dx.doi.org/10.5751/ace-01087-120218

Pickell, P. D., D. W. Andison, N. C. Coops, S. E. Gergel, and P. L. Marshall. 2015. The spatial patterns of anthropogenic disturbance in the western Canadian boreal forest following oil and gas development. Canadian Journal of Forest Research 45:732-743. http://dx.doi.org/10.1139/cjfr-2014-0546

Pollock, K. H. 1982. A capture-recapture design robust to unequal probability of capture. Journal of Wildlife Management 46:752-757. http://dx.doi.org/10.2307/3808568

Pöysä, H., and V.-M. Väänänen. 2014. Drivers of breeding numbers in a long-distance migrant, the Garganey (Anas querquedula): effects of climate and hunting pressure. Journal of Ornithology 155:679-687. http://dx.doi.org/10.1007/s10336-014-1051$\mathrm{y}$

Pradel, R. 1996. Utilization of capture-mark-recapture for the study of recruitment and population growth rate. Biometrics 52:703-709. http://dx.doi.org/10.2307/2532908

Rainio, K., T. Laaksonen, M. Ahola, A. V. Vähätalo, and E. Lehikoinen. 2006. Climatic responses in spring migration of 
boreal and arctic birds in relation to wintering area and taxonomy. Journal of Avian Biology 37:507-515. http://dx.doi.org/10.1111/ j.0908-8857.2006.03740.x

Ray, C., J. F. Saracco, M. L. Holmgren, R. L. Wilkerson, R. B. Siegel, K. J. Jenkins, J. I. Ransom, P. J. Happe, J. R. Boetsch, and M. H. Huff. 2017. Recent stability of resident and migratory landbird populations in National Parks of the Pacific Northwest. Ecosphere 8:e01902. https://dx.doi.org/10.1002/ecs2.1902

Regos, A., L. Imbeau, M. Desrochers, A. Leduc, M. Robert, B. Jobin, L. Brotons, and P. Drapeau. 2018. Hindcasting the impacts of land-use changes on bird communities with species distribution models of Bird Atlas data. Ecological Applications 28:1867-1883. http://dx.doi.org/10.1002/eap.1784

Rempel, R. S., C. M. Francis, J. N. Robinson, and M. Campbell. 2013. Comparison of audio recording system performance for detecting and monitoring songbirds. Journal of Field Ornithology 84:86-97. http://dx.doi.org/10.1111/jofo.12008

Rhodes, J. R., and N. Jonzén. 2011. Monitoring temporal trends in spatially structured populations: how should sampling effort be allocated between space and time? Ecography 34:1040-1048. http://dx.doi.org/10.1111/j.1600-0587.2011.06370.x

Robinson, O. J., C. P. McGowan, and P. K. Devers. 2017. Disentangling density-dependent dynamics using full annual cycle models and Bayesian model weight updating. Journal of Applied Ecology 54:670-678. http://dx.doi.org/10.1111/1365-2664.12761

Rockwell, S. M., C. I. Bocetti, and P. P. Marra. 2012. Carry-over effects of winter climate on spring arrival date and reproductive success in an endangered migratory bird, Kirtland's Warbler (Setophaga kirtlandii). Auk 129:744-752. http://dx.doi.org/10.1525/ auk.2012.12003

Rodenhouse, N. L., T. W. Sherry, and R. T. Holmes. 1997. Sitedependent regulation of population size: a new synthesis. Ecology 78:2025-2042. http://dx.doi.org/10.2307/2265942

Rosenberg, K. V., P. J. Blancher, J. C. Stanton, and A. O. Panjabi. 2017. Use of North American Breeding Bird Survey data in avian conservation assessments. Condor 119:594-606. http://dx.doi. org/10.1650/condor-17-57.1

Rosenberg, K. V., J. A. Kennedy, R. Dettmers, R. P. Ford, D. Reynolds, J. D. Alexander, C. J. Beardmore, P. J. Blancher, R. E. Bogart, G. S. Butcher, A. F. Camfield, A. Couturier, D. W. Demarest, W. E. Easton, J. J. Giocomo, R. H. Keller, A. E. Mini, A. O. Panjabi, D. N. Pashley, T. D. Rich, J. M. Ruth, H. Stabins, J. Stanton, and T. Will. 2016. Partners in flight landbird conservation plan: 2016 revision for Canada and continental United States. Partners in Flight Science Committee, Canadian Wildlife Service, Ottawa, Ontario, Canada. [online] URL: http://www. partnersinflight.org/wp-content/uploads/2016/08/pif-continentalplan-final-spread-single.pdf

Ross, B. E., M. B. Hooten, and D. N. Koons. 2012. An accessible method for implementing hierarchical models with spatiotemporal abundance data. PLoS ONE 7(11):e49395. http://dx. doi.org/10.1371/journal.pone.0049395

Roy, C., E. J. B. McIntire, and S. G. Cumming. 2016. Assessing the spatial variability of density dependence in waterfowl populations. Ecography 39:942-953. http://dx.doi.org/10.1111/ ecog.01534

Royle, J. A. 2004. N-mixture models for estimating population size from spatially replicated counts. Biometrics 60:108-115. http://dx.doi.org/10.1111/j.0006-341x.2004.00142.x

Royle, J. A, and R. M. Dorazio. 2008. Hierarchical modeling and inference in ecology. Academic Press, San Diego, California, USA.

Ruegg, K. C., E. C. Anderson, K. L. Paxton, V. Apkenas, S. Lao, R. B. Siegel, D. F. DeSante, F. Moore, and T. B. Smith. 2014. Mapping migration in a songbird using high-resolution genetic markers. Molecular Ecology 23:5726-5739. http://dx.doi. org/10.1111/mec.12977

Ruiz-Gutierrez, V., W. L. Kendall, J. F. Saracco, and G. C. White. 2016. Overwintering strategies of migratory birds: a novel approach for estimating seasonal movement patterns of residents and transients. Journal of Applied Ecology 53:1035-1045. https:// doi.org/10.1111/1365-2664.12655.

Rushing, C. S., J. A. Hostetler, T. S. Sillett, P. P. Marra, J. A. Rotenberg, and T. B. Ryder. 2017. Spatial and temporal drivers of avian population dynamics across the annual cycle. Ecology 98:2837-2850. http://dx.doi.org/10.1002/ecy.1967

Rushing, C. S., T. B. Ryder, and P. P. Marra. 2016a. Quantifying drivers of population dynamics for a migratory bird throughout the annual cycle. Proceedings of the Royal Society B: Biological Sciences 283:20152846. http://dx.doi.org/10.1098/rspb.2015.2846

Rushing, C. S., T. B. Ryder, A. L. Scarpignato, J. F. Saracco, and P. P. Marra. 2016b. Using demographic attributes from long-term monitoring data to delineate natural population structure. Journal of Applied Ecology 53:491-500. http://dx.doi.org/10.1111/1365-2664.12579

Saracco, J. F., D. F. DeSante, and D. R. Kaschube. 2008. Assessing landbird monitoring programs and demographic causes of population trends. Journal of Wildlife Management 72:1665-1673. http://dx.doi.org/10.2193/2008-129

Saracco, J. F., S. M. Fettig, G. L. San Miguel, D. W. Mehlman, B. E. Thompson, and S. K. Albert. 2018. Avian demographic responses to drought and fire: a community-level perspective. Ecological Applications 28:1773-1781. https://doi.org/10.1002/ eap. 1751

Saracco, J. F., J. A. Royle, D. F. DeSante, and B. Gardner. 2010. Modeling spatial variation in avian survival and residency probabilities. Ecology 91:1885-1891. http://dx.doi.org/10.1890/09-0705.1

Saracco, J. F., J. A. Royle, D. F. DeSante, and B. Gardner. 2012. Spatial modeling of survival and residency and application to the Monitoring Avian Productivity and Survivorship program. Journal of Ornithology 152:469-476. http://dx.doi.org/10.1007/ s10336-010-0565-1

Saracco, J. F., R. B. Siegel, L. Helton, S. L. Stock, and D. F. DeSante. 2019. Phenology and productivity in a montane bird assemblage: trends and responses to elevation and climate variation. Global Change Biology 25:985-996. https://doi. org/10.1111/gcb.14538 
Sauer, J. R., J. E. Hines, G. Gough, I. Thomas, and B. G. Peterjohn. 1997. The North American Breeding Bird Survey results and analysis. Version 96.4. Patuxent Wildlife Research Center, Laurel, Maryland, USA.

Sauer, J. R., and W. A. Link. 2002. Hierarchical modeling of population stability and species group attributes from survey data. Ecology 83:1743-1751. http://dx.doi.org/10.2307/3071992

Sauer, J. R., and W. A. Link. 2011. Analysis of the North American Breeding Bird Survey using hierarchical models. Auk 128:87-98. http://dx.doi.org/10.1525/auk.2010.09220

Sauer, J. R., D. Niven, J. Hines, D. Ziolkowski, Jr., K. L. Pardieck, J. E. Fallon, and W. A. Link. 2017a. The North American Breeding Bird Survey, results and analysis 1966-2015. Version 2.07.2017. U. S. Geological Survey Patuxent Wildlife Research Center, Laurel, Maryland, USA. [online] URL: https://www.mbr-pwrc.usgs.gov/ bbs/

Sauer, J. R., D. K. Niven, K. L. Pardieck, D. J. Ziolkowski, Jr., and W. A. Link. 2017b. Expanding the North American Breeding Bird Survey analysis to include additional species and regions. Journal of Fish and Wildlife Management 8:154-172. https://doi. org/10.3996/102015-JFWM-109

Sauer, J. R., B. G. Peterjohn, and W. A. Link. 1994. Observer differences in the North American Breeding Bird Survey. Auk 111:50-62. http://dx.doi.org/10.2307/4088504

Saunders, S. P., F. J. Cuthbert, and E. F. Zipkin. 2018. Evaluating population viability and efficacy of conservation management using integrated population models. Journal of Applied Ecology 55:1380-1392. http://dx.doi.org/10.1111/1365-2664.13080

Schaub, M., and F. Abadi. 2011. Integrated population models: a novel analysis framework for deeper insights into population dynamics. Journal of Ornithology 152(S1):227-237. http://dx.doi. org/10.1007/s10336-010-0632-7

Schaub, M., O. Gimenez, A. Sierro, and R. Arlettaz. 2007. Use of integrated modeling to enhance estimates of population dynamics obtained from limited data. Conservation Biology 21:945-955. http://dx.doi.org/10.1111/j.1523-1739.2007.00743.x

Schaub, M., J. von Hirschheydt, and M. U. Grüebler. 2015. Differential contribution of demographic rate synchrony to population synchrony in barn swallows. Journal of Animal Ecology 84:1530-1541. http://dx.doi.org/10.1111/1365-2656.12423

Schroeder, T. A., M. A. Wulder, S. P. Healey, and G. G. Moisen. 2011. Mapping wildfire and clearcut harvest disturbances in boreal forests with Landsat time series data. Remote Sensing of Environment 115:1421-1433. http://dx.doi.org/10.1016/j.rse.2011.01.022

Schummer, M. L., A. D. Afton, S. S. Badzinski, S. A. Petrie, G. H. Olsen, and M. A. Mitchell. 2018. Evaluating the waterfowl breeding population and habitat survey for scaup. Journal of Wildlife Management 82:1252-1262. http://dx.doi.org/10.1002/ jwmg. 21478

Schuster, R., S. Wilson, A. D. Rodewald, P. Arcese, D. Fink, T. Auer, and J. R. Bennett. 2019. Optimizing conservation of migratory species over their full annual cycle. Nature Communications 10:1754. https://doi.org/10.1101/268805
Schieck, J. 1997. Biased detection of bird vocalizations affects comparisons of bird abundance among forested habitats. Condor 99:179-190. https://doi.org/10.2307/1370236

Seber, G. A. F. 1970. Estimating time-specific survival and reporting rates for adult birds from band returns. Biometrika 57:313-318. http://dx.doi.org/10.1093/biomet/57.2.313

Senf, C., R. Seidl, and P. Hostert. 2017. Remote sensing of forest insect disturbances: current state and future directions. International Journal of Applied Earth Observation and Geoinformation 60:49-60. http://dx.doi.org/10.1016/j.jag.2017.04.004

Settele, J., R. Scholes, R. Betts, S. Bunn, P. Leadley, D. Nepstad, J. T. Overpeck, and M. A. Taboada. 2014. Climate change 2014: impacts, adaptation, and vulnerability. Part A: global and sectoral aspects. Contribution of Working Group II to the Fifth Assessment Report of the Intergovernmental Panel on Climate Change. Cambridge University Press, Cambridge, UK.

Shonfield, J., and E. M. Bayne. 2017. Autonomous recording units in avian ecological research: current use and future applications. Avian Conservation and Ecology 12(1):14. http://dx.doi. org/10.5751/ace-00974-120114

Simard, M., N. Pinto, J. B. Fisher, and A. Baccini. 2011. Mapping forest canopy height globally with spaceborne lidar. Journal of Geophysical Research: Biogeosciences 116:G04021. http://dx.doi. org/10.1029/2011jg001708

Sinclair, P., Y. Aubry, J. Bart, V. Johnston, R. Lanctot, B. McCaffery, K. Ross, P. Smith, and L. Tibbitts. 2004. Boreal shorebirds: an assessment of conservation status and potential for population monitoring. Program for Regional and International Shorebird Monitoring (PRISM) Boreal Committee, Whitehorse, Yukon Territory, Canada.

Smith, G. W. 1995. A critical review of the aerial and ground surveys of breeding waterfowl in North America. Biological Science Report No. 5. U.S. Department of the Interior, National Biological Service, Laurel, Maryland, USA.

Smith, A. N. H., M. J. Anderson, and M. D. M. Pawley. 2017. Could ecologists be more random? Straightforward alternatives to haphazard spatial sampling. Ecography 40:1251-1255. http:// dx.doi.org/10.1111/ecog.02821

Smith, A. C., M.-A. R. Hudson, C. M. Downes, and C. M. Francis. 2015. Change points in the population trends of aerialinsectivorous birds in North America: synchronized in time across species and regions. PLoS ONE 10(7):e0130768. http://dx.doi. org/10.1371/journal.pone.0130768

Socolar, J. B., P. N. Epanchin, S. R. Beissinger, and M. W. Tingley. 2018. Phenological shifts conserve thermal niches in North American birds and reshape expectations for climate-driven range shifts. Proceedings of the National Academy of Sciences of the United States of America 114:12976-12981. https://doi. org/10.1073/pnas.1705897114

Sollmann, R., B. Gardner, and J. L. Belant. 2012. How does spatial study design influence density estimates from spatial capturerecapture models? PLOS ONE 7(4):e34575. http://dx.doi. org/10.1371/journal.pone. 0034575 
Sollmann, R., B. Gardner, R. B. Chandler, J. A. Royle, and T. S. Sillett. 2015. An open-population hierarchical distance sampling model. Ecology 96:325-331. http://dx.doi.org/10.1890/14-1625.1

Sollmann, R., B. Gardner, K. A. Williams, A. T. Gilbert, and R. R. Velt. 2016. A hierarchical distance sampling model to estimate abundance and covariate associations of species and communities. Methods in Ecology and Evolution 7:529-537. http:// dx.doi.org/10.1111/2041-210x.12518

Sólymos, P., S. Lele, and E. Bayne. 2012. Conditional likelihood approach for analyzing single visit abundance survey data in the presence of zero inflation and detection error. Environmetrics 23:197-205. http://dx.doi.org/10.1002/env.1149

Sólymos, P., S. M. Matsuoka, E. M. Bayne, S. R. Lele, P. Fontaine, S. G. Cumming, D. Stralberg, F. K. A. Schmiegelow, and S. J. Song. 2013. Calibrating indices of avian density from nonstandardized survey data: making the most of a messy situation. Methods in Ecology and Evolution 4:1047-1058. http://dx.doi. org/10.1111/2041-210x.12106

Soykan, C. U., J. Sauer, J. G. Schuetz, G. S. LeBaron, K. Dale, and G. M. Langham. 2016. Population trends for North American winter birds based on hierarchical models. Ecosphere 7(5):e01351. http://dx.doi.org/10.1002/ecs2.1351

Stenseth, N. C., G. Ottersen, J. W. Hurrell, A. Mysterud, M. Lima, K.-S. Chan, N. G. Yoccoz, and B. Ådlandsvik. 2003. Studying climate effects on ecology through the use of climate indices: the North Atlantic Oscillation, El Niño Southern Oscillation and beyond. Proceedings of the Royal Society B: Biological Sciences 270:2087-2096. http://dx.doi.org/10.1098/rspb.2003.2415

Stralberg, D., S. M. Matsuoka, A. Hamann, E. M. Bayne, P. Sólymos, F. K. A. Schmiegelow, X. Wang, S. G. Cumming, and S. J. Song. 2015. Projecting boreal bird responses to climate change: the signal exceeds the noise. Ecological Applications 25:52-69. http://dx.doi.org/10.1890/13-2289.1

Strong, C., B. Zuckerberg, J. L. Betancourt, and W. D. Koenig. 2015. Climatic dipoles drive two principal modes of North American boreal bird irruption. Proceedings of the National Academy of Sciences of the United States of America 112(21): E2795-E2802. http://dx.doi.org/10.1073/pnas. 1418414112

Taylor, C. M., and B. J. M. Stutchbury. 2016. Effects of breeding versus winter habitat loss and fragmentation on the population dynamics of a migratory songbird. Ecological Applications 26:424-437. http://dx.doi.org/10.1890/14-1410

Tempel, D. J., M. Z. Peery, and R. J. Gutiérrez. 2014. Using integrated population models to improve conservation monitoring: California spotted owls as a case study. Ecological Modelling 289:86-95. http://dx.doi.org/10.1016/j.ecolmodel.2014.07.005

Terraube, J., A. Villers, L. Poudré, R. Varjonen, and E. Korpimäki. 2017. Increased autumn rainfall disrupts predatorprey interactions in fragmented boreal forests. Global Change Biology 23:1361-1373. http://dx.doi.org/10.1111/gcb.13408

Thompson, S. J., C. M. Handel, and L. B. McNew. 2017. Autonomous acoustic recorders reveal complex patterns in avian detection probability. Journal of Wildlife Management 81:1228-1241. http://dx.doi.org/10.1002/jwmg.21285
Tillé, Y., and A.-C. Favre. 2005. Optimal allocation in balanced sampling. Statistics \& Probability Letters 74:31-37. http://dx.doi. org/10.1016/j.spl.2005.04.027

Tingley, M. W., and S. R. Beissinger. 2013. Cryptic loss of montane avian richness and high community turnover over 100 years. Ecology 94:598-609. http://dx.doi.org/10.1890/12-0928.1

Tingley, M. W., W. B. Monahan, S. R. Beissinger, and C. Moritz. 2009. Birds track their Grinnellian niche through a century of climate change. Proceedings of the National Academy of Sciences of the United States of America 106:19637-19643. https://doi. org/10.1073/pnas.0901562106

Turgeon, P. J., S. L. Van Wilgenburg, and K. L. Drake. 2017. Microphone variability and degradation: implications for monitoring programs employing autonomous recording units. Avian Conservation and Ecology 12(1):9. https://doi.org/10.5751/ ACE-00958-120109

Twedt, D. J., and R. R. Wilson. 2017. Breeding birds in managed forests on public conservation lands in the Mississippi Alluvial Valley. Forest Ecology and Management 384:180-190. http://dx. doi.org/10.1016/j.foreco.2016.10.031

Urquhart, N. S. 2012. The role of monitoring design in detecting trend in long-term ecological monitoring studies. Pages 151-173 in R. A. Gitzen, J. J. Millspaugh, A. B. Cooper, and D. S. Licht, editors. Design and analysis of long-term ecological monitoring studies. Cambridge University Press, Cambridge, UK. https://doi. org/10.1017/CBO9781139022422.011

Urquhart, N. S., and T. M. Kincaid. 1999. Designs for detecting trend from repeated surveys of ecological resources. Journal of Agricultural, Biological, and Environmental Statistics 4:404-414. http://dx.doi.org/10.2307/1400498

Van Wilgenburg, S. L., E. M. Beck, B. Obermayer, T. Joyce, and B. Weddle. 2015. Biased representation of disturbance rates in the roadside sampling frame in boreal forests: implications for monitoring design. Avian Conservation and Ecology 10(2):5. http://dx.doi.org/10.5751/ACE-00777-100205

Van Wilgenburg, S. L., and K. A. Hobson. 2008. Landscape-scale disturbance and boreal forest birds: can large single-pass harvest approximate fires? Forest Ecology and Management 256:136-146. http://dx.doi.org/10.1016/j.Foreco.2008.04.017

Van Wilgenburg, S. L., K. A. Hobson, K. J. Kardynal, and E. M. Beck. 2018. Temporal changes in avian abundance in aspendominated boreal mixedwood forests of central Saskatchewan, Canada. Avian Conservation and Ecology 13(1):3. https://doi. org/10.5751/ACE-01145-130103

Van Wilgenburg, S. L., P. Sólymos, K. J. Kardynal, and M. D. Frey. 2017. Paired sampling standardizes point count data from humans and acoustic recorders. Avian Conservation and Ecology 12(1):13. https://doi.org/10.5751/ACE-00975-120113

Vas, E., A. Lescroël, O. Duriez, G. Boguszewski, and D. Grémillet. 2015. Approaching birds with drones: first experiments and ethical guidelines. Biology Letters 11:20140754. http://dx.doi. org/10.1098/rsbl.2014.0754

Venier, L. A., and S. B. Holmes. 2010. A review of the interaction between forest birds and eastern spruce budworm. Environmental Reviews 18:191-207. http://dx.doi.org/10.1139/a10-009 
Venier, L. A., S. B. Holmes, G. W. Holborn, K. A. McIlwrick, and G. Brown. 2012a. Evaluation of an automated recording device for monitoring forest birds. Wildlife Society Bulletin 36:30-39. http://dx.doi.org/10.1002/wsb.88

Venier, L. A., S. B. Holmes, J. L. Pearce, and R. E. Fournier. $2012 b$. Misleading correlations: the case of the Canada warbler and spruce budworm. Journal of Wildlife Management 76:294-298. http://dx.doi.org/10.1002/jwmg.257

Venier, L. A., I. D. Thompson, R. Fleming, J. Malcolm, I. Aubin, J. A. Trofymow, D. Langor, R. Sturrock, C. Patry, R. O. Outerbridge, S. B. Holmes, S. Haeussler, L. De Grandpré, H. Y. H. Chen, E. Bayne, A. Arsenault, and J. P. Brandt. 2014. Effects of natural resource development on the terrestrial biodiversity of Canadian boreal forests. Environmental Reviews 22:457-490. http://dx.doi.org/10.1139/er-2013-0075

Virkkala, R. 2016. Long-term decline of southern boreal forest birds: consequence of habitat alteration or climate change? Biodiversity and Conservation 25:151-167. http://dx.doi. org/10.1007/s10531-015-1043-0

Vold, S. T., C. M. Handel, and L. B. McNew. 2017. Comparison of acoustic recorders and field observers for monitoring tundra bird communities. Wildlife Society Bulletin 41:566-576. http://dx. doi.org/10.1002/wsb.785

Ward, M. P., K. W. Stodola, J. W. Walk, T. J. Benson, J. L. Deppe, and J. D. Brawn. 2018. Changes in bird distributions in Illinois, USA, over the 20th century were driven by alternative rather than primary habitats. Condor 120:622-631. http://dx.doi.org/10.1650/ CONDOR-17-153.1

Webster, K. L., F. D. Beall, I. F. Creed, and D. P. Kreutzweiser. 2015. Impacts and prognosis of natural resource development on water and wetlands in Canada's boreal zone. Environmental Reviews 23:78-131. http://dx.doi.org/10.1139/er-2014-0063

Weegman, M. D., S. Bearhop, A. D. Fox, G. M. Hilton, A. J. Walsh, J. L. McDonald, and D. J. Hodgson. 2016. Integrated population modelling reveals a perceived source to be a cryptic sink. Journal of Animal Ecology 85:467-475. http://dx.doi. org/10.1111/1365-2656.12481

Wellicome, T. I., K. J. Kardynal, R. J. Franken, and C. S. Gillies. 2014. Off-road sampling reveals a different grassland bird community than roadside sampling: implications for survey design and estimates to guide conservation. Avian Conservation and Ecology 9(1):4. http://dx.doi.org/10.5751/ace-00624-090104

Wells, J. V., and P. J. Blancher. 2011. Global role for sustaining bird populations. Pages 7-21 in J. V. Wells, editor. Boreal birds of North America: a hemispheric view of their conservation links and significance. University of California Press, Berkeley, California, USA.

Westgate, M. J., G. E. Likens, and D. B. Lindenmayer. 2013. Adaptive management of biological systems: a review. Biological Conservation 158:128-139. http://dx.doi.org/10.1016/j.biocon.2012.08.016

Whitaker, D. M., P. D. Taylor, and I. G. Warkentin. 2008. Survival of adult songbirds in boreal forest landscapes fragmented by clearcuts and natural openings. Avian Conservation and Ecology 3(1):5. http://dx.doi.org/10.5751/ace-00223-030105
White, J. C., M. A. Wulder, G. W. Hobart, J. E. Luther, T. Hermosilla, P. Griffiths, N. C. Coops, R. J. Hall, P. Hostert, A. Dyk and L. Guindon. 2014. Pixel-based image compositing for large-area dense time series applications and science. Canadian Journal of Remote Sensing 40:192-212. https://doi. org/10.1080/07038992.2014.945827

Williams, B. K., and E. D. Brown. 2016. Technical challenges in the application of adaptive management. Biological Conservation 195:255-263. https://doi.org/10.1016/j.biocon.2016.01.012

Williams, B. K., J. D. Nichols, and M. D. Conroy. 2002. Analysis and management of animal populations. Academic Press, New York, New York, USA.

Williams, B. K., R. C. Szaro, and C. D. Shapiro. 2007. Adaptive management: the U.S. Department of the Interior technical guide. U.S. Department of the Interior, Washington, D.C., USA.

Wilson, S., S. L. LaDeau, A. P. Tøttrup, and P. P. Marra. 2011. Range-wide effects of breeding- and nonbreeding-season climate on the abundance of a Neotropical migrant songbird. Ecology 92:1789-1798. http://dx.doi.org/10.1890/10-1757.1

Wilson, S., J. F. Saracco, R. Krikun, D. T. Tyler Flockhart, C. M. Godwin, and K. R. Foster. 2018. Drivers of demographic decline across the annual cycle of a threatened migratory bird. Scientific Reports 8:7316. https://doi.org/10.1038/s41598-018-25633-z

Wintle, B. A., M. C. Runge, and S. A. Bekessy. 2010. Allocating monitoring effort in the face of unknown unknowns. Ecology Letters 13:1325-1337. https://dx.doi.org/10.1111/j.1461-0248.2010.01514. $\mathrm{x}$

Woods, S. 2017. Generalized additive models: an introduction with $R$. Second edition. CRC Press, Boca Raton, Florida, USA.

Yamaura, Y., J. A. Royle, K. Kuboi, T. Tada, S. Ikeno, and S. Makino. 2011. Modelling community dynamics based on specieslevel abundance models from detection/nondetection data. Journal of Applied Ecology 48:67-75. https://doi.org/10.1111/ j.1365-2664.2010.01922.x

Yip, D. A., L. Leston, E. M. Bayne, P. Sólymos, and A. Grover. 2017. Experimentally derived detection distances from audio recordings and human observers enable integrated analysis of point count data. Avian Conservation and Ecology 12(1):11. https://doi.org/10.5751/ACE-00997-120111

Zald, H. S. J., M. A. Wulder, J. C. White, T. Hilker, T. Hermosilla, G. W. Hobart, and N. C. Coops. 2016. Integrating Landsat pixel composites and change metrics with lidar plots to predictively map forest structure and aboveground biomass in Saskatchewan, Canada. Remote Sensing of Environment 176:188-201. http://dx. doi.org/10.1016/j.rse.2016.01.015

Zhao, Q., G. S. Boomer, and J. A. Royle, 2019. Integrated modeling predicts shifts in waterbird population dynamics under climate change. Ecography, in press. http://dx.doi.org/10.1111/ ecog.04548

Zimmerling, J. R., C. M. Francis, C. Roy, and A. M. Calvert. 2017. How well does forestry in Ontario's boreal forest emulate natural disturbances from the perspective of birds? Avian Conservation and Ecology 12(2):10. http://dx.doi.org/10.5751/ACE-01102-120210 
Zimmerman, G. S., R. J. Gutiérrez, W. E. Thogmartin, and S. Banerjee. 2009. Multiscale habitat selection by Ruffed Grouse at low population densities. Condor 111:294-304. http://dx.doi. org/10.1525/cond.2009.080036

Zimmerman, G. S., J. R. Sauer, W. A. Link, and M. Otto. 2012. Composite analysis of black duck breeding population surveys in eastern North America. Journal of Wildlife Management 76 (6):1165-1176. https://dx.doi.org/10.1002/jwmg.351

Zipkin, E. F., and S. P. Saunders. 2018. Synthesizing multiple data types for biological conservation using integrated population models. Biological Conservation 217:240-250. https://doi. org/10.1016/j.biocon.2017.10.017

Zuur, A. F., R. J. Fryer, I. T. Jolliffe, R. Dekker, and J. J. Beukema. 2003. Estimating common trends in multivariate time series using dynamic factor analysis. Environmetrics 14:665-685. http://dx.doi. org/10.1002/env.611

Zuur, A. F., E. N. Ieno, and G. M. Smith. 2007. Time series analysis - introduction. Pages 265-268 in A. F. Zuur, E. N. Ieno, and G. M. Smith, editors. Analysing ecological data. Springer, New York, New York, USA. https://doi.org/10.1007/978-0-387-45972-1_16 